Prepared in cooperation with the Montana Department of Natural Resources and Conservation

\title{
Methods for Peak-Flow Frequency Analysis and Reporting for Streamgages in or near Montana Based on Data through Water Year 2015
}

Scientific Investigations Report 2018-5046 



\section{Methods for Peak-Flow Frequency Analysis and Reporting for Streamgages in or near Montana Based on Data through Water Year 2015}

By Steven K. Sando and Peter M. McCarthy

Prepared in cooperation with the Montana Department of Natural Resources and Conservation

Scientific Investigations Report 2018-5046 


\title{
U.S. Department of the Interior \\ RYAN K. ZINKE, Secretary
}

\section{U.S. Geological Survey William H. Werkheiser, Deputy Director exercising the authority of the Director}

\author{
U.S. Geological Survey, Reston, Virginia: 2018
}

For more information on the USGS - the Federal source for science about the Earth, its natural and living resources, natural hazards, and the environment-visit https://www.usgs.gov or call 1-888-ASK-USGS.

For an overview of USGS information products, including maps, imagery, and publications, visit https://store.usgs.gov.

Any use of trade, firm, or product names is for descriptive purposes only and does not imply endorsement by the U.S. Government.

Although this information product, for the most part, is in the public domain, it also may contain copyrighted materials as noted in the text. Permission to reproduce copyrighted items must be secured from the copyright owner.

Suggested citation:

Sando, S.K., and McCarthy, P.M., 2018, Methods for peak-flow frequency analysis and reporting for streamgages in or near Montana based on data through water year 2015: U.S. Geological Survey Scientific Investigations Report 2018-5046, 39 p., https://doi.org/10.3133/sir20185046.

ISSN 2328-0328 (online) 


\section{Contents}

Acknowledgments ……..............................................................................................................

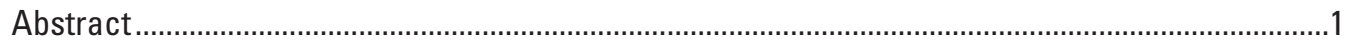

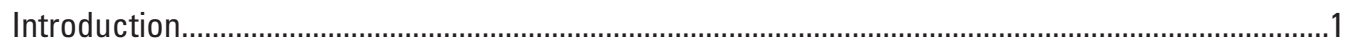

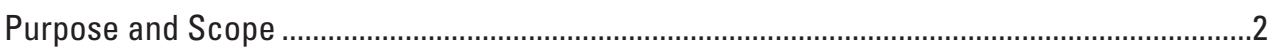

Selected Peak-Flow Frequency Analysis Terminology ............................................................

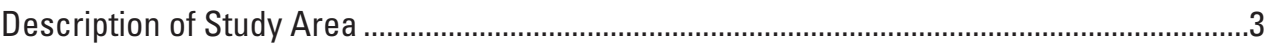

Brief Overview of Unusually Large Floods in Montana ..........................................................

Overview of Bulletin 17B and Bulletin 17C Guidelines for Peak-Flow Frequency Analysis ..............8

The Expected Moments Algorithm Procedures in Relation to Montana Peak-Flow Datasets.........9

Selected Considerations for Peak-Flow Frequency Analysis .......................................................11

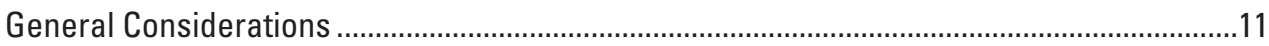

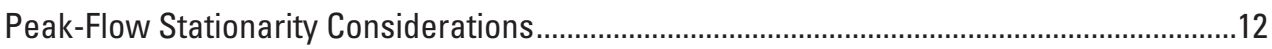

Methods for Peak-Flow Frequency Analysis .............................................................................12

Data Collection, Compilation, and Pre-Analysis Data Combination and Correction ................12

Pre-Analysis Data Combination ...............................................................................18

Pre-Analysis Data Correction ....................................................................................

Determination of Regulation Status of Streamgages ............................................................19

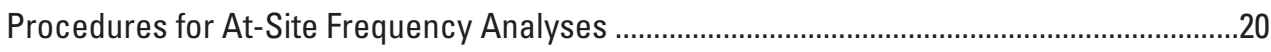

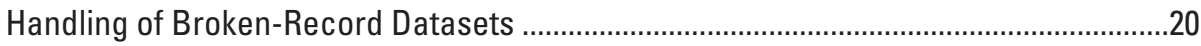

Standard Procedures for Implementing the Bulletin 17C Guidelines ............................20

Standard Procedures for Weighted Skew Coefficients .........................................20

Standard Procedures for Handling Potentially Influential Low Flows ....................21

Standard Procedures for Incorporating Historical Information ..............................21

Standard Procedures for Setting Flow Intervals and Perception Thresholds

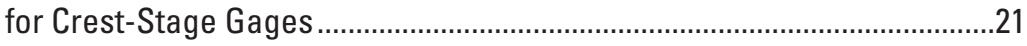

Informed-User Adjustments to Bulletin 17C Guidelines .................................................22

Adjustments for Handling Regulated Peak-Flow Records....................................22

Adjustments for Handling Atypical Upper-Tail Peak-Flow Records.........................24

Adjustments for Handling Atypical Lower-Tail Peak-Flow Records .......................27

Considerations for Interpreting At-Site Frequency Analyses ..........................................30

Procedures for Improving At-Site Frequency Analyses ......................................................30

Procedures for Weighting with Regional Regression Equations...................................30

Considerations for Interpreting Frequency Results for Weighting with

Regional Regression Equations ..................................................................31

Procedures for Modified Maintenance of Variance Extension Type III Record

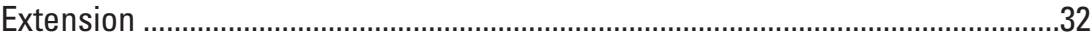

Definition of Base Periods......................................................................................32

Application of Modified Maintenance of Variance Extension Type III

Procedures to Synthesize Peak-Flow Data ...............................................32

Procedures for Frequency Analysis of Extended Peak-Flow Datasets....................33

Considerations for Interpreting Frequency Results for Extended Peak-Flow

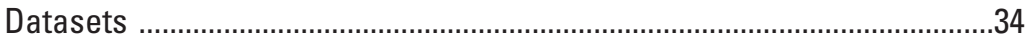

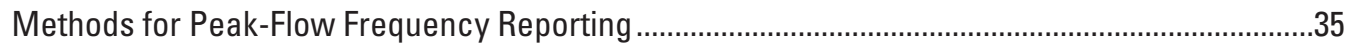

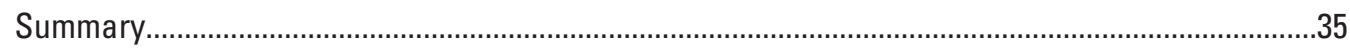

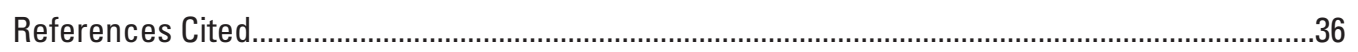




\section{Figures}

1. Map showing hydrologic regions in Montana and locations of selected streamgages for which example peak-flow frequency analyses are reported.

2. Statistical distributions of proportions of peak flows in each month for streamgages in each hydrologic region

3. PeakFQv7.1 output-Peak-flow frequency curves for Flint Creek near Southern

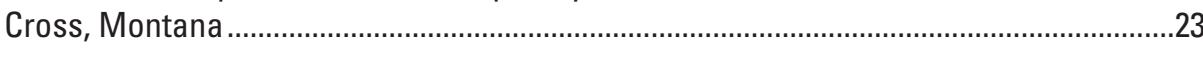

4. PeakFQv7.1 output-Peak-flow frequency curves for Tenmile Creek near Rimini, Montana

5. PeakFQv7.1 output-Peak-flow frequency curves for Denniel Creek near Val Marie, Saskatchewan

6. PeakFQv7.1 output-Peak-flow frequency curves for Poplar River at international boundary.

\section{Tables}

1. Information on hydrologic regions in Montana ..............................................................5

2. Hydrologic regions and general flood characteristics in Montana ..................................6

3. Information on streamgages that serve as examples of various peak-flow frequency analysis procedures

4. Description of tables in the data releases associated with this report ...........................18 


\section{Conversion Factors}

U.S. customary units to International System of Units

\begin{tabular}{|c|c|c|}
\hline Multiply & By & To obtain \\
\hline \multicolumn{3}{|c|}{ Length } \\
\hline inch (in.) & 2.54 & centimeter $(\mathrm{cm})$ \\
\hline inch (in.) & 25.4 & millimeter (mm) \\
\hline foot $(\mathrm{ft})$ & 0.3048 & meter (m) \\
\hline mile (mi) & 1.609 & kilometer (km) \\
\hline \multicolumn{3}{|c|}{ Area } \\
\hline square mile $\left(\mathrm{mi}^{2}\right)$ & 259.0 & hectare (ha) \\
\hline square mile $\left(\mathrm{mi}^{2}\right)$ & 2.590 & square kilometer $\left(\mathrm{km}^{2}\right)$ \\
\hline \multicolumn{3}{|c|}{ Volume } \\
\hline acre-foot (acre-ft) & 1,233 & cubic meter $\left(\mathrm{m}^{3}\right)$ \\
\hline \multicolumn{3}{|c|}{ Flow rate } \\
\hline cubic foot per second $\left(\mathrm{ft}^{3} / \mathrm{s}\right)$ & 0.02832 & cubic meter per second $\left(\mathrm{m}^{3} / \mathrm{s}\right)$ \\
\hline
\end{tabular}

Temperature in degrees Fahrenheit $\left({ }^{\circ} \mathrm{F}\right)$ may be converted to degrees Celsius $\left({ }^{\circ} \mathrm{C}\right)$ as follows:

$$
{ }^{\circ} \mathrm{C}=\left({ }^{\circ} \mathrm{F}-32\right) / 1.8 \text {. }
$$

\section{Datum}

Vertical coordinate information is referenced to the North American Vertical Datum of 1988 (NAVD 88).

Horizontal coordinate information is referenced to the North American Datum of 1983 (NAD 83).

Elevation, as used in this report, refers to distance above the vertical datum.

\section{Supplemental Information}

Water year is the 12-month period from 0ctober 1 through September 30 of the following calendar year. The water year is designated by the calendar year in which it ends. For example, water year 2015 is the period from October 1, 2014, through September 30, 2015. 


\section{Abbreviations}

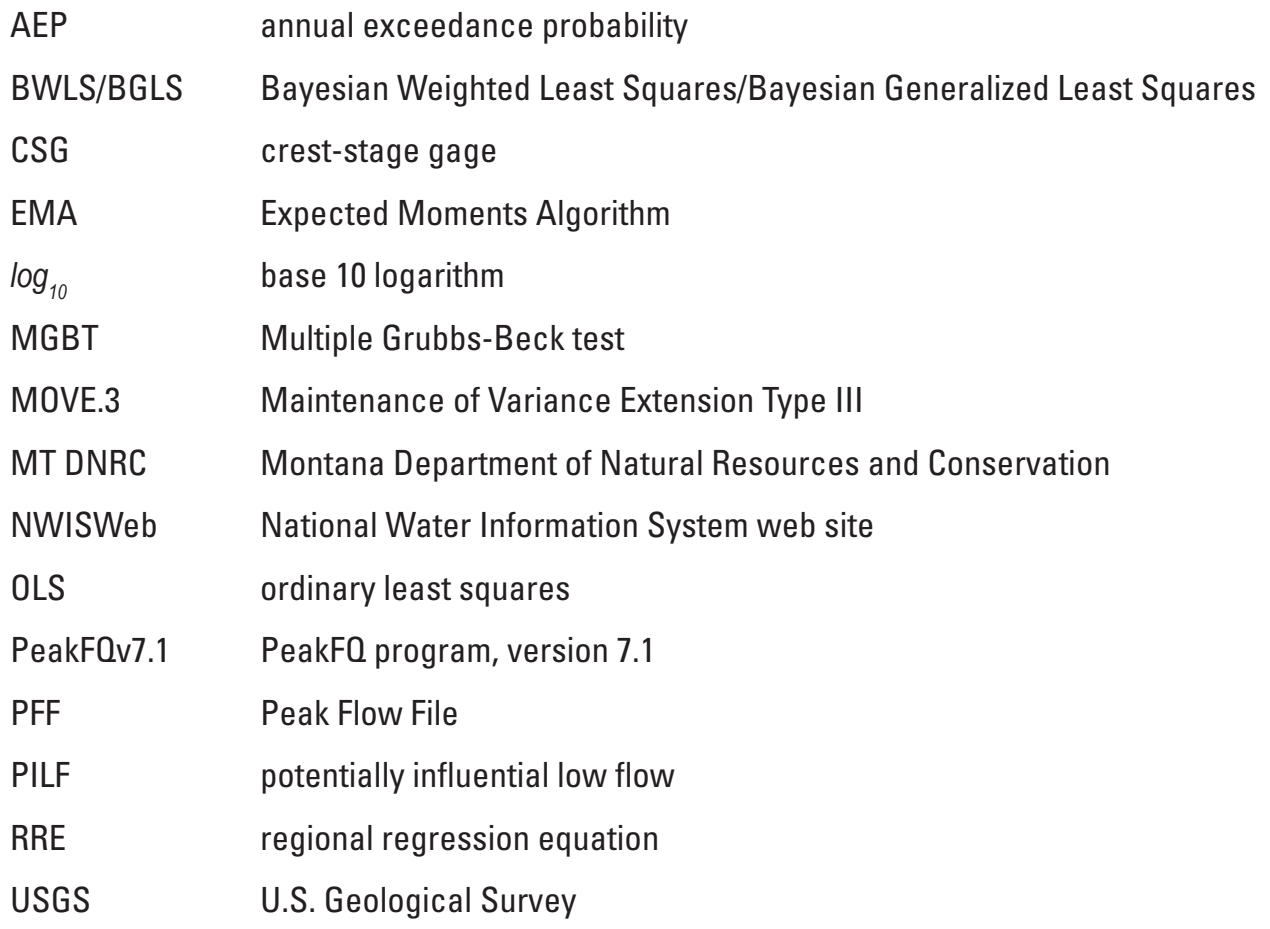

\section{Acknowledgments}

Thanks are given to Greg Pederson of the U.S. Geological Survey for assistance with describing climatic processes in Montana. The authors would like to recognize the U.S. Geological Survey hydrologic technicians involved in the collection of streamflow data for their dedicated efforts. The authors also would like to recognize the valuable contributions to this report from the insightful technical reviews by Dan Driscoll, Charles Parrett (retired), Aldo (Skip) Vecchia (retired), Karen Ryberg, Julie Kiang, and Andrea Veilleux of the U.S. Geological Survey.

Special thanks are given to Steve Story, Walter Ludlow, and Nicole Decker of the Montana Department of Natural Resources and Conservation for their support of this study. Thanks also are given to Will Thomas of Michael Baker International for expert assistance with recordextension statistics. 


\title{
Methods for Peak-Flow Frequency Analysis and Reporting for Streamgages in or near Montana Based on Data through Water Year 2015
}

\author{
By Steven K. Sando and Peter M. McCarthy
}

\section{Abstract}

This report documents the methods for peak-flow frequency (hereinafter "frequency") analysis and reporting for streamgages in and near Montana following implementation of the Bulletin 17C guidelines. The methods are used to provide estimates of peak-flow quantiles for 50-, 42.9-, 20-, 10-, 4-, 2-, 1-, 0.5-, and 0.2-percent annual exceedance probabilities for selected streamgages operated by the U.S. Geological Survey Wyoming-Montana Water Science Center (WY-MT WSC). These annual exceedance probabilities correspond to 2-, 2.33-, 5-, 10-, 25-, 50-, 100-, 200-, and 500-year recurrence intervals, respectively.

Standard procedures specific to the WY-MT WSC for implementing the Bulletin 17C guidelines include (1) the use of the Expected Moments Algorithm analysis for fitting the log-Pearson Type III distribution, incorporating historical information where applicable; (2) the use of weighted skew coefficients (based on weighting at-site station skew coefficients with generalized skew coefficients from the Bulletin 17B national skew map); and (3) the use of the Multiple Grubbs-Beck Test for identifying potentially influential low flows. For some streamgages, the peak-flow records are not well represented by the standard procedures and require userspecified adjustments informed by hydrologic judgement. The specific characteristics of peak-flow records addressed by the informed-user adjustments include (1) regulated peakflow records, (2) atypical upper-tail peak-flow records, and (3) atypical lower-tail peak-flow records. In all cases, the informed-user adjustments use the Expected Moments Algorithm fit of the log-Pearson Type III distribution using the atsite station skew coefficient, a manual potentially influential low flow threshold, or both.

Appropriate methods can be applied to at-site frequency estimates to provide improved representation of long-term hydroclimatic conditions. The methods for improving at-site frequency estimates by weighting with regional regression equations and by Maintenance of Variance Extension Type III record extension are described.
Frequency analyses were conducted for 99 example streamgages to indicate various aspects of the frequencyanalysis methods described in this report. The frequency analyses and results for the example streamgages are presented in a separate data release associated with this report consisting of tables and graphical plots that are structured to include information concerning the interpretive decisions involved in the frequency analyses. Further, the separate data release includes the input files to the PeakFQ program, version 7.1, including the peak-flow data file and the analysis specification file that were used in the peak-flow frequency analyses. Peakflow frequencies are also reported in separate data releases for selected streamgages in the Beaverhead River and Clark Fork Basins and also for selected streamgages in the Ruby, Jefferson, and Madison River Basins.

\section{Introduction}

Many agencies, including the Montana Department of Natural Resources and Conservation (MT DNRC), have continuing needs for peak-flow information for flood-plain mapping, design of highway infrastructure, and many other purposes. Recently, a study was completed by the U.S. Geological Survey (USGS) to provide an update of statewide peak-flow frequency (hereinafter "frequency") analyses for Montana following Bulletin 17B guidelines (U.S. Interagency Advisory Committee on Water Data, 1982; hereinafter "Bulletin 17B") based on data through water year 2011 (Sando and others 2016a). In Montana, statewide frequency analyses have been updated and reported about every 10 to 15 years (for example, Omang, 1992; Parrett and Johnson, 2004; and Sando and others, 2016a); however, individuals and agencies often need updated frequency analyses that incorporate new peak-flow data collected during the long intervals between the statewide reports.

The MT DNRC recently requested that the USGS provide updated frequency analyses for selected streamgages to complete flood-plain mapping projects in the Beaverhead, 
Ruby, Jefferson, and Madison River Basins and the Clark Fork Basin. The request specifically included the use of new methods for frequency analysis presented in an update of the national guidelines for flood-frequency analysis: Bulletin 17C (England and others, 2017; hereinafter "Bulletin $\left.17 C^{\prime \prime}\right)$. Further, MT DNRC has indicated a need for updated frequency analyses in the future, which could be facilitated by development of a streamlined process for timely reporting of frequency analyses.

\section{Purpose and Scope}

The purpose of this report is to document the methods for frequency analysis and reporting for streamgages in and near Montana following implementation of the Bulletin 17C guidelines. The methods are used to provide estimates of peak-flow quantiles for 50-, 42.9-, 20-, 10-, 4-, 2-, 1-, 0.5-, and 0.2-percent annual exceedance probabilities (AEPs) for selected streamgages operated by the WY-MT WSC. These AEPs correspond to 2-, 2.33-, 5-, 10-, 25-, 50-, 100-, 200-, and 500 -year recurrence intervals, respectively.

This report reviews the Bulletin 17B and Bulletin 17C guidelines and discusses the use of the Bulletin $17 \mathrm{C}$ guidelines in conjunction with specific user-specified adjustments informed by hydrologic judgement for application to streamgages in or near Montana. The informed-user adjustments to the Bulletin 17C guidelines are documented. Frequency analyses are presented for 99 example streamgages to indicate various aspects of the frequencyanalysis methods. The frequency analyses and results for the example streamgages are presented in a separate data release (McCarthy and others, 2018a) consisting of tables and graphical plots that are structured to include information concerning the interpretive decisions involved in the frequency analyses. In addition to the tables, the frequency curves and associated information are presented in the data release in separate worksheets for each frequency analysis; hyperlinks in the tables allow convenient access to the frequency curves and associated information. Further, the separate data release includes the peak-flow data file and the analysis specification file that were used in the peak-flow frequency analyses.

An approach for timely publication of updated frequency analyses is presented. The approach entails thorough documentation of frequency-analysis methods in an interpretive report in conjunction with a data release for 99 example streamgages consisting of tables and graphical plots that include information concerning the interpretive decisions involved in the frequency analyses (McCarthy and others, 2018a). The approach also is used to report peakflow frequencies based on data through water year 2016 for selected streamgages in the Beaverhead River and Clark Fork Basins (McCarthy and others, 2018b) and also for selected streamgages in the Ruby, Jefferson, and Madison River Basins (McCarthy and others, 2018c).

\section{Selected Peak-Flow Frequency Analysis Terminology}

In this report, the terms "peak flow" and "flood" are used in the discussion of streamflow characteristics. A flood is any high streamflow that overtops the natural or artificial banks of a stream and is defined on the basis of stage. An annual peak flow is the annual maximum instantaneous discharge recorded for each water year (October 1 through September 30 and designated by the calendar year in which it ends) that an individual streamgage is operated and is defined on the basis of discharge. The stage associated with a given annual peak flow might not overtop the river banks and thus the peak flow might not qualify as a flood. Conversely, multiple floods that overtop the stream banks might happen in a single year. In various frequency-analysis literature the terms "peak flow" and "flood" are sometimes used synonymously. In this report, "peak flow" is the preferred term in referring to discharge-based data; however, in some cases "flood" is used in describing large streamflow events that exceed river banks and also in discussion of information taken from references in which the terms "peak flow" and "flood" are used synonymously.

Throughout this report, extensive reference is made to the national guidelines (Bulletin 17B [U.S. Interagency Advisory Committee on Water Data, 1982] and Bulletin 17C [England and others, 2017]) for flood-frequency analysis and in many cases specific citations are presented; however, in some cases phrases and terminology from the national guidelines are used without citation. The intent is to facilitate presentation of information, not to misrepresent wording as having originated with the authors of this report. Substantial reliance on the guidelines is acknowledged.

In this report, the term "peak-flow quantile" (and sometimes "flood quantile") is commonly used. The peak-flow or flood quantile is the discharge magnitude associated with an AEP as determined by frequency analysis.

In this report, the term "conservative" sometimes is used in relation to frequency analysis. In considering multiple possible formulations of a frequency analysis in relation to various frequency applications, a conservative estimate is the largest estimate, which might be most appropriate for protection of life and property.

The term "systematic record" describes peak-flow data that are collected at regular, prescribed intervals under a defined protocol, generally during multiple consecutive years of data collection. A more detailed definition of the term is presented in the section "Handling of Broken-Record Datasets."

A "reliable frequency estimate" is considered a frequency analysis that, within available data and methods, (1) reasonably adheres to a valid statistical approach; (2) results in a frequency curve that reasonably represents the peak-flow plotting positions in a probability plot; and (3) provides reasonable transition, within the context of updated data and methods, 
from previously reported frequency analyses that generally have proven reliable. Further, the reliability of a frequency analysis is supported by consistency with the hydrologic regime represented by the streamgage.

\section{Description of Study Area}

The study area primarily consists of the State of Montana. The description of the study area focuses on factors relating to the flood hydrology of Montana and issues relating to operation of a large statewide streamgage network within Montana.

Montana is a large State $\left(147,000\right.$ square miles $\left.\left[\mathrm{mi}^{2}\right]\right)$ with large spatial variability in geologic, topographic, ecologic, and climatic characteristics; the large variability in these characteristics translates to large spatial variability in hydrologic regimes. Six Level III Ecoregions (U.S. Environmental Protection Agency, 2015) are represented in Montana (Northern Rockies, Canadian Rockies, Idaho Batholith, Middle Rockies, Northwestern Glaciated Plains, and Northwestern Great Plains) with large variability in characteristics among the ecoregions. Somewhat abrupt transitions can exist among high-elevation mountains with intermontane valleys; welldrained, low-elevation plains; poorly drained, low-elevation glaciated prairies; and other complex geologic and hydrologic features. Various aspects of the transitions result in complex hydrology across Montana.

Parrett and Johnson (2004) identified eight hydrologic regions in Montana to describe streamflow characteristics (fig. 1). Various topographic, climatic, and land-use characteristics of the hydrologic regions are presented in table 1. Further information for the regions, including general flood characteristics for each region, is presented in table 2.

Major drivers of peak-flow events in Montana include snowmelt, rainfall, and snowmelt with rainfall. Across Montana, large variability in climatic and topographic characteristics affects the spatial dominance among the major drivers and results in large variability in the flood regimes of streamgages. A brief overview of climatic and topographic characteristics that are relevant to Montana flood hydrology follows. Observations are presented based on consideration of mean monthly temperature and precipitation characteristics in Montana (PRISM Climate Group, 2015), as well as principles described by Mock (1996), Zelt and others (1999), Knowles and others (2006), Pederson and others (2011), and Shinker (2010). The discussion might be facilitated by reference to tables 1 and 2 and figure 2, which provides information on the seasonal timing of peak flows.

Large snowpacks frequently accumulate during late fall through early spring in the mountainous parts of western Montana. Hydrologic regions 1, 2, 7, and 8 all have substantial areas with elevations exceeding 6,000 feet and mean annual precipitation exceeding that of the other four hydrologic regions (fig. 1, table 1). Much of the annual precipitation in the mountainous regions can occur as snowfall and much of the annual runoff typically is from snowmelt. Most annual peak flows in hydrologic regions 1, 2, 7, and 8 occur in May and June (fig. 2) in association with high-elevation snowmelt and sometimes spring rainfall. Low-elevation plains areas of eastern Montana are represented in hydrologic regions 3, 4, 5, and 6 . Winter precipitation in the eastern plains is substantially lower than in the western mountains. In the eastern plains, most of the annual precipitation occurs as spring and summer rainfall. The timing of annual peak flows in the eastern plains is more variable than in the western mountains. Hydrologic regions 3, 4, 5, and 6 can have substantial proportions of peak flows in March through July (fig. 2), which are affected by low-elevation snowmelt and spring and summer rainfall.

In areas of Montana east of the Rocky Mountain Front, May and June typically have the highest mean monthly precipitation, which typically occurs as rainfall. The Rocky Mountain Front is where the eastern slopes of the Rocky Mountains meet the plains in the Northwest and Northwest Foothills hydrologic regions, and parts of the Southwest hydrologic region (fig. 1). During spring, two major sources provide moisture for the region: (1) warm moist air masses are advected into the region because of the formation of the low-level jet, which advects moisture northward from the Gulf of Mexico (Mock, 1996; Shinker, 2010); and (2) northwesterly flows of moisture from the northern Pacific Ocean in conjunction with the formation of major frontal systems and unstable air masses, all of which result from cool-season atmospheric circulation patterns (Mock, 1996; Shinker, 2010). Convective storms also can develop behind the cyclonic frontal systems and further contribute to spring precipitation. Runoff from spring rainfall (alone or in combination with snowmelt) is a major driver of many peak flows in Montana. Monthly mean precipitation typically decreases (sometimes sharply) from June through September as warm stable air masses build across the Pacific Northwest and northern Rocky Mountains (Mock, 1996; Shinker, 2010); however, convective summer thunderstorms in the eastern plains can be intense and result in flash flooding.

In contrast to areas east of the Rocky Mountain Front, in mountainous areas of western Montana, the cool season (fall and winter) precipitation totals often exceed the spring (May and June) precipitation totals, which can result in large accumulated mountain snowpacks. Much lower precipitation totals and smaller amounts of accumulated snowpack, however, are common in lower elevation areas, especially in plains areas east of the Rocky Mountain Front. The timing and relative contribution of snowmelt runoff to streamflow is strongly dependent on spring temperatures, which reflect the importance of elevation and, to a lesser extent, latitude on snowmelt timing (Pederson and others, 2011). In low-elevation areas throughout Montana, snowmelt runoff generally is in late winter through early spring (Zelt and others, 1999), typically before May, and the timing of annual peak flows that result from low-elevation snowmelt runoff typically is somewhat distinctly separated from the timing of annual peak flows that result from spring precipitation or summer convective storms. 


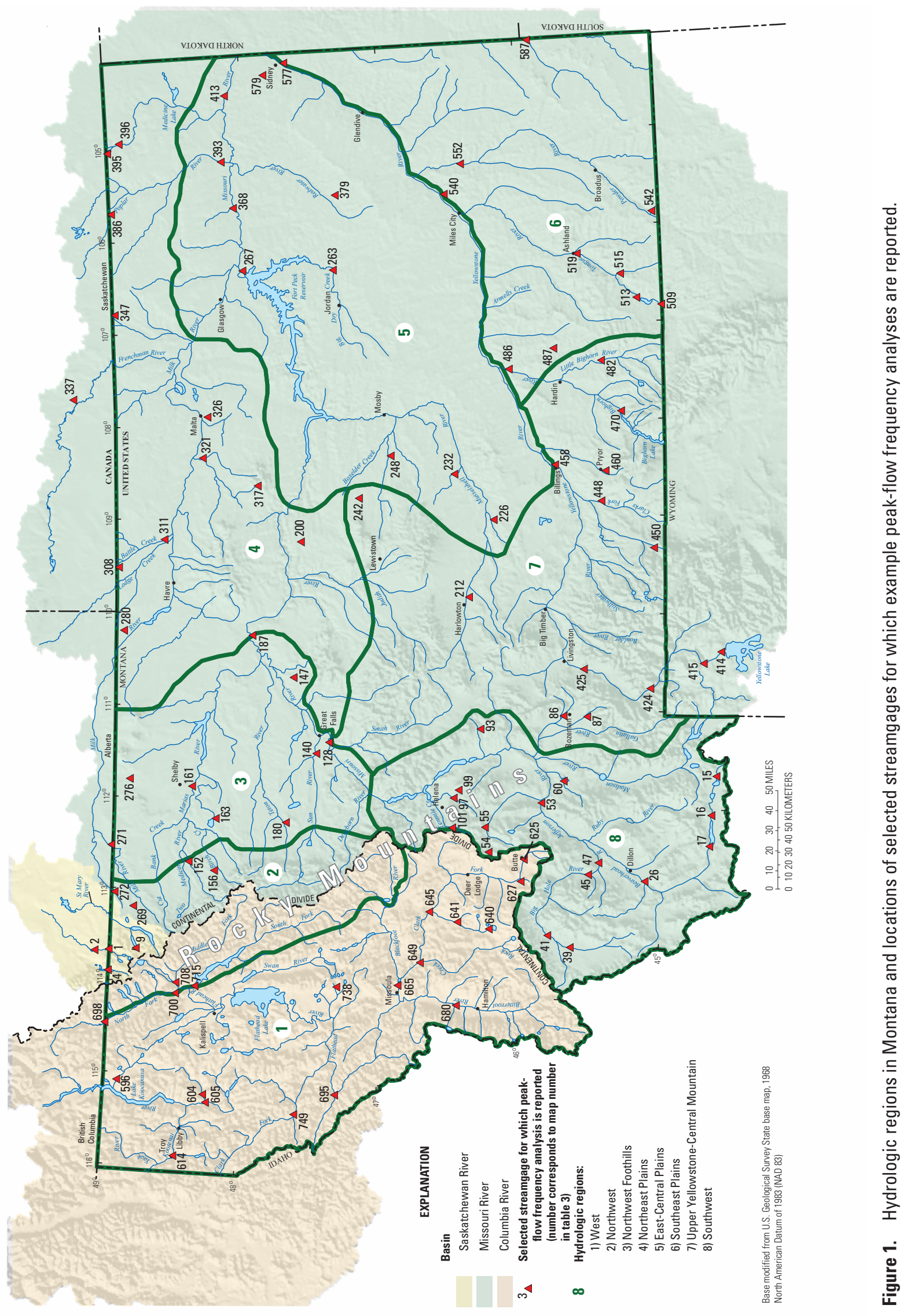




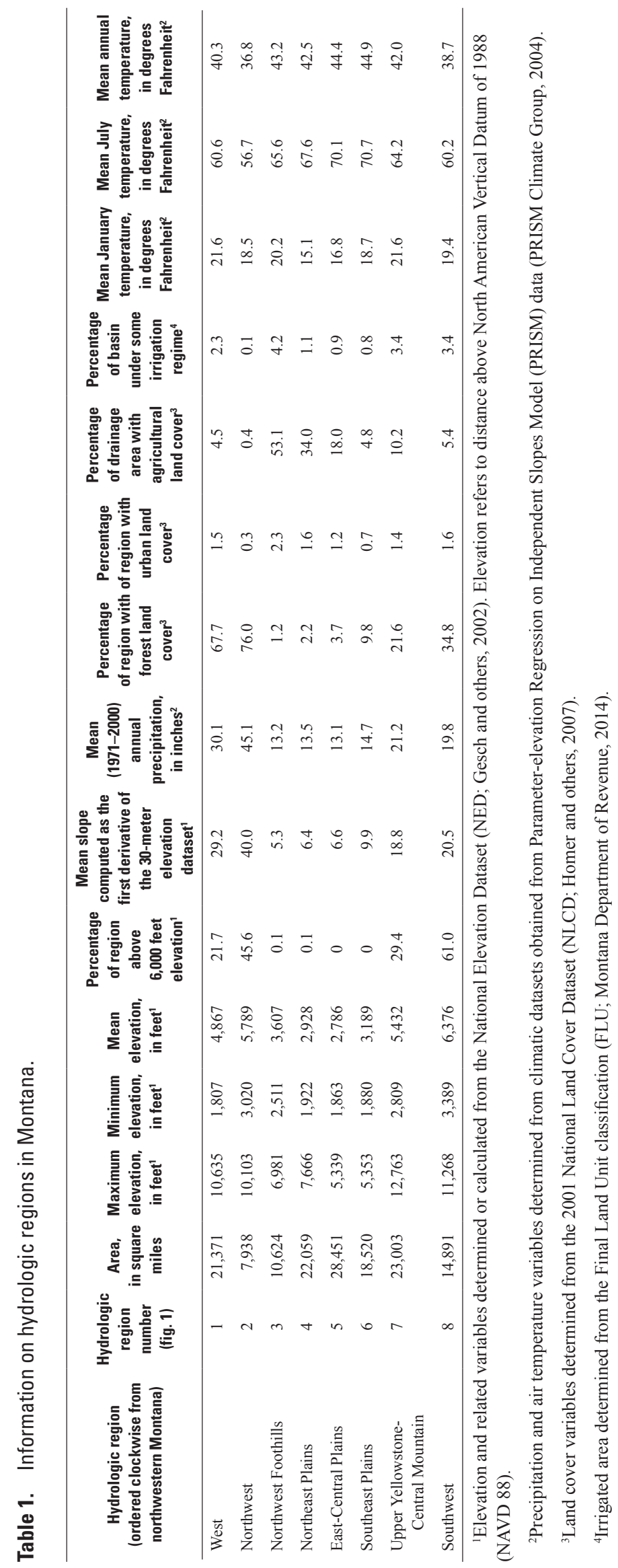


Table 2. Hydrologic regions and general flood characteristics in Montana (modified from Parrett and Johnson, 2004).

\begin{tabular}{|c|c|c|c|}
\hline $\begin{array}{l}\text { Hydrologic region } \\
\text { (ordered clockwise } \\
\text { from northwestern } \\
\text { Montana) }\end{array}$ & $\begin{array}{l}\text { Hydrologic } \\
\text { region } \\
\text { number } \\
\text { (fig. 1) }\end{array}$ & General description and extent & General flood characteristics \\
\hline West & 1 & $\begin{array}{l}\text { Mountains and valleys west of Continental } \\
\text { Divide; parts of Flathead and Blackfoot } \\
\text { River Basins }\end{array}$ & $\begin{array}{l}\text { Most floods caused by snowmelt or snowmelt mixed with rain. Annual } \\
\text { peak flows less variable than in other regions. }\end{array}$ \\
\hline Northwest & 2 & $\begin{array}{l}\text { Eastern parts of Flathead and Blackfoot } \\
\text { River Basins; mountains and foothills east } \\
\text { of the Continental Divide and northeast of } \\
\text { Missoula, Montana }\end{array}$ & $\begin{array}{l}\text { Largest floods caused by runoff from rain associated with moist air masses } \\
\text { from the Gulf of Mexico. Most annual peak flows are from snowmelt or } \\
\text { snowmelt mixed with rain. }\end{array}$ \\
\hline Northwest Foothills & 3 & $\begin{array}{l}\text { Foothills and plains of the Marias, Teton, } \\
\text { Sun, and Dearborn River Basins near } \\
\text { Great Falls, Montana }\end{array}$ & $\begin{array}{l}\text { Floods caused by snowmelt, large amounts of rain, or thunderstorms. An- } \\
\text { nual peak flows are more variable than those from similar-sized streams } \\
\text { in the mountainous regions. }\end{array}$ \\
\hline Northeast Plains & 4 & $\begin{array}{l}\text { Rolling plains of the Milk River Basin up- } \\
\text { stream from Glasgow; foothills and plains } \\
\text { part of the Judith River Basin }\end{array}$ & $\begin{array}{l}\text { Floods on larger streams caused by prairie snowmelt or snowmelt mixed } \\
\text { with rain. Most floods on smaller streams caused by thunderstorms. } \\
\text { Annual peak flows are more variable than those from streams in the } \\
\text { Northwest Foothills region. }\end{array}$ \\
\hline East-Central Plains & 5 & $\begin{array}{l}\text { Plains and badlands of the lower parts of } \\
\text { Musselshell, Missouri, Milk, and Poplar } \\
\text { River Basins; northern part of Yellowstone } \\
\text { River Basin east of Billings, Montana }\end{array}$ & $\begin{array}{l}\text { Floods on larger streams caused by prairie snowmelt or snowmelt mixed } \\
\text { with rain. Most floods on smaller streams caused by thunderstorms. } \\
\text { Thunderstorms are more prevalent and intense than in any other region. } \\
\text { Annual peak flows are more variable than in any other region. }\end{array}$ \\
\hline Southeast Plains & 6 & $\begin{array}{l}\text { Rolling plains of southern part of Yel- } \\
\text { lowstone River Basin east of Billings, } \\
\text { Montana }\end{array}$ & $\begin{array}{l}\text { Floods on larger streams caused by prairie snowmelt or snowmelt mixed } \\
\text { with rain. Most floods on smaller streams caused by thunderstorms. An- } \\
\text { nual peak flows are somewhat less variable and smaller than those from } \\
\text { similar-sized streams in the East-Central Plains region. }\end{array}$ \\
\hline $\begin{array}{l}\text { Upper Yellowstone- } \\
\text { Central Mountain }\end{array}$ & 7 & $\begin{array}{l}\text { Mountains and valleys of the upper Yellow- } \\
\text { stone River Basin; mountains and valleys } \\
\text { of the Smith River Basin; parts of the } \\
\text { Judith and Musselshell River Basins }\end{array}$ & $\begin{array}{l}\text { Floods caused by snowmelt or snowmelt mixed with rain on larger streams } \\
\text { and snowmelt or thunderstorms on smaller streams. Annual peak flows } \\
\text { are similar to, though more variable than, those in the West region. }\end{array}$ \\
\hline Southwest & 8 & $\begin{array}{l}\text { Mountains and valleys of the Missouri River } \\
\text { Basin upstream from the Dearborn River }\end{array}$ & $\begin{array}{l}\text { Floods caused by snowmelt or snowmelt mixed with rain on larger streams } \\
\text { and snowmelt or thunderstorms on smaller streams. Annual peak flows } \\
\text { generally are smaller and more variable than those from similar-sized } \\
\text { streams in other mountainous regions. }\end{array}$ \\
\hline
\end{tabular}

With increase in elevation, the timing of snowmelt runoff is later in the year. In high-elevation areas, most snowmelt typically is from May through mid-July (Pederson and others, 2011); the typical snowmelt runoff period and the typical spring rainfall period are somewhat synchronized, and the relative contributions of snowmelt and rainfall runoff are difficult to distinguish. Difficulties in distinguishing the effects of snowmelt and rainfall on peak flows in high-elevation areas also have been noted by Pederson and others (2011). In general, one overall result of the patterns is that a snowmelt hydrologic regime is more clearly dominant in interior mountain areas of western Montana than in plains areas east of the Rocky Mountain Front.

With an area of 147,000 $\mathrm{mi}^{2}$, Montana ranks 4th among States in the United States in size; however, Montana ranks 47 th in population and 46th in tax base (U.S. Census Bureau, 2016). In conjunction with large variability in hydrologic regimes, the socioeconomic characteristics of Montana present substantial challenges for operating a large statewide streamgage network that consistently captures the hydrologic variability. These characteristics also translate into complexities and challenges in frequency analysis for Montana streamgages.

\section{Brief Overview of Unusually Large Floods in Montana}

Selected large floods are generally described in the following paragraphs to facilitate understanding of various conditions that contribute to floods in Montana. O'Connor and Costa (2003) indicate that the spatial distribution of large floods is related to specific combinations of regional climatology, topography, and proximity to oceanic moisture sources such as the Pacific Ocean and Gulf of Mexico; these observations are relevant to the occurrence of large floods in Montana. The selected large floods frequently rank in the top 10 percent of peak flows for individual streamgages and often are used in frequency analyses that incorporate historical information, either in defining historical peak flows or in determining 


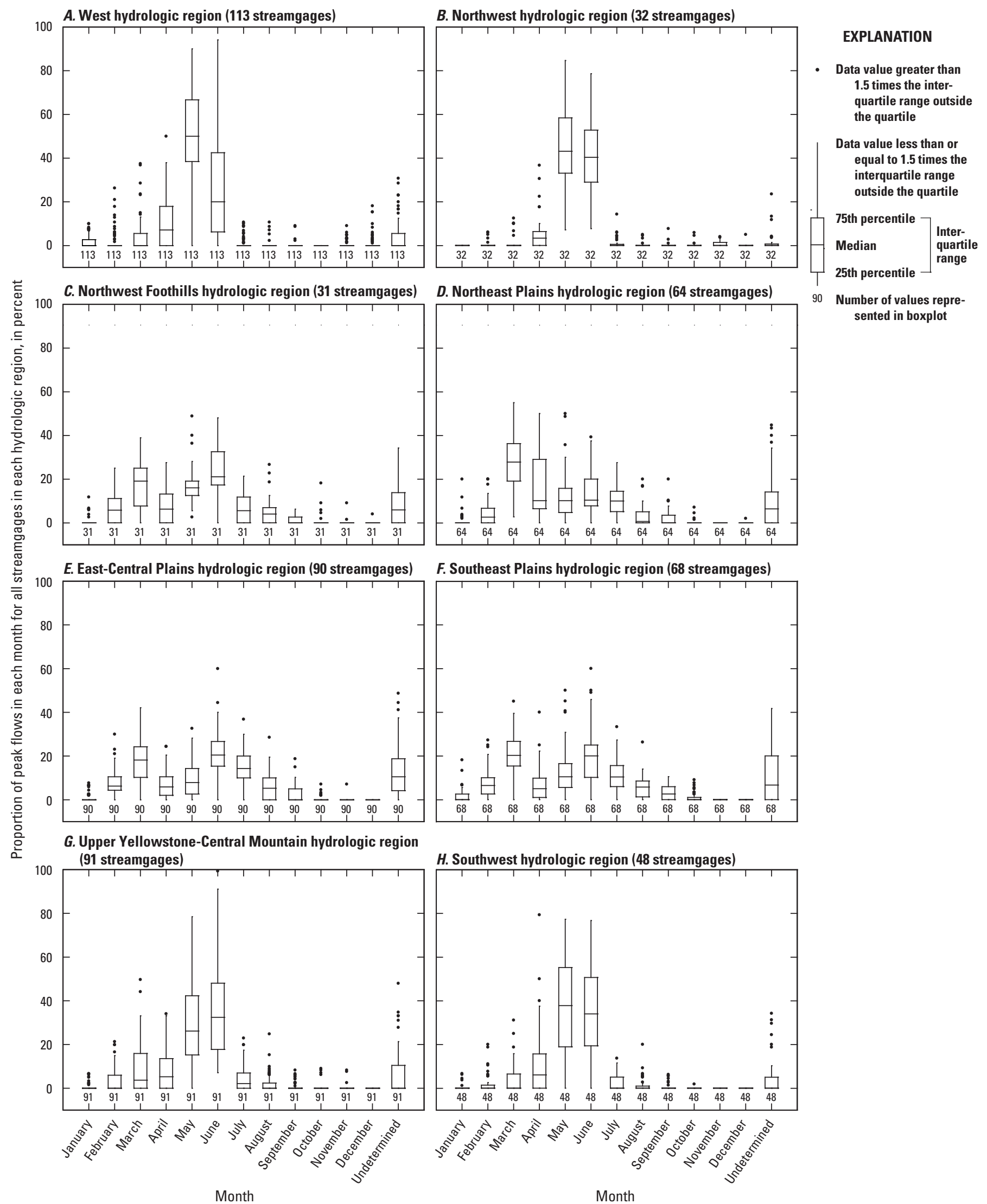

Figure 2. Statistical distributions of proportions of peak flows in each month for streamgages in each hydrologic region. $A$, West (region 1); $B$, Northwest (region 2); $C$, Northwest Foothills (region 3); $D$, Northeast Plains (region 4); $E$, East-Central Plains (region 5); F, Southeast Plains (region 6); G, Upper Yellowstone-Central Mountain (region 7); and H, Southwest (region 8) (Sando, Roy, and others, 2016) 
appropriate flow intervals and perception thresholds in ungaged periods (as described in the sections "The Expected Moments Algorithm Procedures in Relation to Montana PeakFlow Datasets" and "Standard Procedures for Incorporating Historical Information").

In northwestern and west-central Montana, particularly in areas near or adjacent to the Continental Divide and Rocky Mountain Front, there have been several notable large regional floods with generally similar climatic conditions. The floods occurred in May or June and there was interaction of large, moist air masses advected from the Gulf of Mexico in conjunction with Pacific frontal systems and orographic effects that produced intense rainfall in periods near the peak of snowmelt runoff. The antecedent snowpacks typically were near or above average. The large regional floods of 1908 (National Weather Service, 2016), 1953 (Wells, 1957), 1964 (Boner and Stermitz, 1967), and 1975 (Johnson and Omang, 1976) provide the best representation of the described conditions. Boner and Stermitz (1967) also note large floods with similar conditions in 1894, 1916, and 1948.

In north-central Montana, primarily in low-elevation plains areas in the Milk River Basin, a notable large regional snowmelt flood occurred in April 1952 (Wells, 1955). The flood was associated with an unusually large snowpack that rapidly melted during unusually warm spring temperatures; rainfall was not a contributing factor. The flooding was amplified by frozen-soil conditions and ice-jam releases, factors sometimes associated with late-winter and early-spring breakup events in association with transition from ice-cover to open-channel conditions.

Mostly in the western part of Montana, atmospheric rivers can deliver large amounts of moisture from the Pacific Ocean typically in early fall through late winter. Atmospheric rivers are moisture-laden narrow bands that spin off of Pacific cyclonic systems and under specific conditions result in intense precipitation (Barth and others, 2017). When atmospheric rivers are associated with above average temperatures, intense rainfall can produce unusual cool-season flooding. Examples of large atmospheric river floods include the January 1974 flood in northwestern Montana (Johnson and Omang, 1974), the November 2006 flood in northwestern Montana (Barth and others, 2017), and the September 1986 flood in north-central Montana (Montana Department of Military Affairs, 2010). Flooding associated with cool-season floods can be amplified by frozen-soil conditions and ice-jam releases (U.S. Army Corps of Engineers, 1991, 1998), factors sometimes associated with breakup events that more typically occur in late winter and early spring.

Unusually wet winters and springs in 1978 and 2011 resulted in large accumulated snowpacks throughout much of Montana (National Weather Service, 2016; Parrett and others, 1978; Vining and others, 2013; Holmes and others, 2013). Flood conditions generally were above normal statewide, but intense rainfall in May 1978 in southeastern Montana and in May 2011 in north-central and southeastern Montana produced unusually large floods.
In May 1981, intense rainfall combined with snowmelt produced severe flooding in west-central Montana focused in the upper Missouri River Basin from near Helena to near Bozeman and in the upper Clark Fork Basin near Deer Lodge (Parrett and others, 1982). The antecedent snowpacks generally were below to near normal. In May 1984, intense rainfall combined with snowmelt produced severe flooding in southwestern Montana (U.S. Army Corps of Engineers, 1985; Montana Department of Military Affairs, 2010).

\section{Overview of Bulletin 17B and Bulletin 17C Guidelines for Peak-Flow Frequency Analysis}

Bulletin $17 \mathrm{C}$ represents the latest in a series of national guidelines for frequency analysis by Federal agencies and provides a detailed review of the history of the national guidelines. Bulletin 17C supersedes Bulletin 17B with updates that include a new generalized representation of flood data that allows interval and censored data types within the Expected Moments Algorithm (EMA; Cohn and others, 1997) for fitting the log-Pearson Type III distribution, use of the Multiple Grubbs-Beck test (MGBT; Cohn and others, 2013) for identifying potentially influential low flows (PILFs; sometimes also referred to as "Potentially Influential Low Floods"), and an improved method for computing confidence intervals.

Bulletin 17B was based on frequency-curve fitting procedures that used point-value peak-flow estimates (peak-flow records) with special adjustments to account for historical peak flows, and very low and zero peak flows. The Bulletin 17B approach was not efficient in handling of historical information, low outliers, zero peak flows, and censored peak-flow observations. The EMA procedures described in Bulletin 17C use a general description of a total period of peak-flow record, which includes both systematic record and, where applicable, historical information; within the total period, representations of peak-flow observations are generalized to include concepts such as flow intervals, exceedances, nonexceedances, and perception thresholds. In relation to Bulletin 17B, the Bulletin $17 \mathrm{C}$ use of the MGBT is more effective in detecting PILFs and the EMA procedures are more effective in handling the PILFs, which otherwise would have a distorting effect on the upper tail of the fitted frequency curve. Bulletin $17 \mathrm{C}$ also includes a new method for record extension using a Maintenance of Variance Extension approach that incorporates aspects of the "Two Station Comparison" (Matalas and Jacobs, 1964; Bulletin 17B) and Maintenance of Variance Extension Type III (MOVE.3; Vogel and Stedinger, 1985); record extension can be used to improve at-site frequency estimates so they are more representative of long-term hydroclimatic conditions. For frequency analyses that do not incorporate historical information and also do not have censored peak-flow observations 
or PILFs identified by the MGBT, frequency estimates based on Bulletin 17C essentially are identical to estimates based on Bulletin 17B; however, Bulletin 17C provides more accurate estimation of confidence intervals about the frequency curve that generally results in somewhat larger confidence intervals.

The Bulletin $17 \mathrm{C}$ guidelines represent a national-scale model that is applicable to a large majority of frequency applications in the United States; however, certain aspects of Montana peak-flow datasets do not fit well within the assumptions and guidance of Bulletin $17 \mathrm{C}$ and require special consideration. As such, the Bulletin $17 \mathrm{C}$ guidelines are implemented by the WY-MT WSC with the inclusion of specific informed-user adjustments. Bulletin $17 \mathrm{C}$ notes that the guidelines should be followed unless there are compelling technical reasons for deviations and in such cases the deviations should be documented and supported. Throughout the section "Methods for Peak-Flow Frequency Analysis," cases of deviation from the Bulletin 17C guidelines are noted, documented, and supported.

\section{The Expected Moments Algorithm Procedures in Relation to Montana Peak-Flow Datasets}

This section considers various issues relating to implementing the EMA procedures in relation to Montana peak-flow datasets, especially with respect to incorporating historical information. Currently (2018), the WY-MT WSC conducts EMA frequency analyses using the PeakFQ program (version 7.1; hereinafter "PeakFQv7.1"; U.S. Geological Survey, 2016b; Veilleux and others, 2014); future analyses will be conducted using official updates of the PeakFQ program.

Representation of peak-flow data in the flow-interval and perception-threshold framework of EMA is a major advance in frequency analysis. The EMA framework provides consistent handling of uncensored and censored peak-flow records and also consistent handling of historical information and systematic peak-flow data within a single framework. Uncensored peak-flow records have known magnitudes in known perceptible ranges and are directly incorporated into the EMA computations. Censored peak-flow records result from (1) data-collection activities with sampling properties that restrict the perceptible range of flows (for example, crest-stage gages) and (2) analytical procedures that remove inappropriate effects of PILFs.

In the EMA procedures the total peak-flow period of record (Bulletin 17C; hereinafter "total period") contains both systematic record and, where applicable, historical information and missing years of record. For each year in the total period, a flow interval and a perception threshold are specified, either manually by the analyst or by the default settings and processing in PeakFQv7.1. A flow interval describes the range within which the peak flow is known with reasonable confidence to have been. A perception threshold, also referred to as perceptible range, describes (with reasonable confidence) the potential range within which a peak flow could have been perceived, quantified, and recorded.

For years with uncensored peak-flow records, specification of flow intervals and perception thresholds generally is uncomplicated. For a given year with an uncensored peak-flow record, the lower and upper bounds of the flow interval are set to the recorded peak flow because for practical purposes a measured peak flow can be assumed to be exact (Bulletin 17C). In association with the flow interval, the lower and upper bounds of the perception threshold are set to zero and infinity, respectively, under the assumption that the peak flow could be quantified throughout the full range of potential peakflow magnitudes.

For years with censored peak-flow records, specification of flow intervals and perception thresholds reflect the type of censoring. For example, crest-stage gage (CSG) operations (further described in the sections "Data Collection, Compilation, and Pre-Analysis Data Combination and Correction" and "Standard Procedures for Setting Flow Intervals and Perception Thresholds for Crest-Stage Gages") potentially have sampling properties that restrict the perceptible range of flows. In a given year, streamflow might or might not have attained the lowest measurement point (gage base) of the CSG. In the case of no streamflow above the gage base, with no additional information, the lower and upper bounds of the flow interval are set to 0 and the gage base, respectively, because those bounds describe the range within which the peak flow is known to have been. In the case of streamflow above the gage base, the lower and upper bounds of the flow interval are set to the measured peak flow. In association with the flow intervals for CSGs, in the absence of additional information concerning streamflow below the gage base, the lower and upper bounds of the perception threshold for all years are set to the gage base and infinity, respectively. The WY-MT WSC CSG peak-flow datasets generally do not contain specific gage-base information for all years of their periods of record. As such, setting flow intervals and perception thresholds for the CSG peak-flow datasets requires special considerations, as discussed in the section "Standard Procedures for Setting Flow Intervals and Perception Thresholds for Crest-Stage Gages."

In the case of a peak-flow dataset with analytical censoring of PILFs, for years with peak-flow records above the PILF threshold, the lower and upper bounds of the flow intervals are set to the magnitudes of the peak flows, which reflects the original pre-censoring settings. For years with peak-flow records below the PILF threshold, the lower and upper bounds of the flow intervals are redefined to 0 and the PILF threshold, respectively. In association with the flow intervals, the lower and upper bounds of the perception thresholds for nearly all years with peak-flow records are redefined to the PILF threshold and infinity, respectively; the rare exception being a temporary raising of the gage base of a CSG to a level above the PILF threshold. 
Frequency analyses that incorporate historical information involve peak-flow datasets that contain one or more recorded large peak flows (either within or outside of the systematic record) that are known with reasonable confidence to have not been exceeded during a specified ungaged period. In such frequency analyses, the total period contains systematic record, generally one or more historical peak flows, and ungaged periods.

Sando and others (2016a) reported frequency analyses that included historical adjustments following the guidelines of Bulletin 17B for more than 200 Montana streamgages. With respect to incorporating historical information, transitioning from the Bulletin 17B historical adjustment framework to the flow interval and perception threshold framework of Bulletin $17 \mathrm{C}$ involves several considerations concerning the Montana peak-flow datasets in relation to the EMA framework.

The earliest recorded peak flow in Montana was in 1872 , but routine systematic peak-flow record collection did not start until 1890 , and only 12 streamgages had systematic record collection before 1900. From 1900 to the early 1950s the streamgage network variably increased to about 275 streamgages and since the early 1950 s the streamgage network has fluctuated between about 200 and 250 streamgages (Wayne Berkas, U.S. Geological Survey, written commun., December 2016). As a whole, the Montana streamgage network currently (2018) has about 725 streamgages with 10 or more years of peak-flow records. Within the complex setting of the Montana streamgage network, there are numerous cases of streamgages with peak-flow records outside of systematic record periods (that is, nonsystematic peak-flow records) and also numerous cases of streamgages with multiple segments of systematic record with intervening ungaged periods. Handling of historical information in the EMA framework involves (1) evaluation of nonsystematic peak-flow records to determine their relevance as historical information, (2) evaluation of large systematic peak-flow records to determine their relevance with respect to historical information, and (3) appropriate specification of flow intervals and perception thresholds in ungaged periods.

Much of the complexity in applying the EMA flow interval and perception threshold framework to WY-MT WSC datasets involves appropriate estimation of the lower bound of the perception threshold for ungaged periods. Ideally, prescribed protocols would clearly define the conditions that would result in the acquisition of a peak-flow record outside of the systematic record; that is, there might be specific triggering stage markers (independent of actual peak flows), such as marks on bridges or buildings, and also set protocols for monitoring and documenting whether or not the stage markers were exceeded in ungaged periods. Detailed prescribed protocols for defining and monitoring the lower bounds of perception thresholds would rigorously accommodate the EMA procedures of Bulletin 17C. However, the WY-MT WSC peak-flow datasets were not collected within a rigorous perception threshold framework. Discussion of how the WY-MT WSC peak-flow datasets were collected is relevant to better understand how the datasets can be accommodated within the Bulletin 17C framework.

Throughout the history of the Montana streamgage network, there are numerous cases of streamgage discontinuations and reactivations that have resulted in broken records; about one-half of the 725 streamgages presented in Sando and others (2016a) have one or more breaks in the systematic records. In the operations of the Montana streamgage network, the hydrographers routinely made special responses to unusually large floods and recorded annual peak flows at previously ungaged locations or at discontinued streamgages that resulted in nonsystematic peak-flow records. The special-response records were not based on exceedance of specific perception thresholds but they provide general evidence of the magnitudes of floods that would be perceived and quantified during ungaged periods. As such, with careful handling the specialresponse records might be used to define "best-available" perception thresholds.

In previous reporting of frequency analyses for Montana streamgages (Parrett and Johnson, 2004; Sando and others, 2016a), the special-response records were handled within Bulletin 17B guidelines for historical adjustments. Expert hydrologic investigations were used to determine with reasonable confidence if the special-response records were not exceeded during some ungaged historical period longer than the systematic record. For a specific special-response record at a specific streamgage, the investigations included consideration of information in the streamgage history files, the flood history of other streamgages on the same channel, and the flood history of streamgages with similar hydrology in nearby drainage basins. Geospatial analysis of large floods also has been used in many cases, as described by Sando and others (2016a). The results of the investigations were documented in hard-copy archives associated with Parrett and Johnson (2004) and in table 1-5 of Sando and others (2016a). However, the historical information has not been consistently incorporated into the electronic Peak Flow File (PFF) database that is accessed on the USGS National Water Information System web site (NWISWeb; U.S. Geological Survey, 2016a).

With respect to incorporating historical information in Bulletin 17C frequency analyses, the WY-MT WSC currently (2018) uses "best-available" flow intervals and perception thresholds based on consideration of unusually large floods within the systematic record and also special-response records outside of the systematic record. Hydrologic investigations are used to determine if a specific flood was not exceeded during an associated ungaged historical period within the total period, with consideration of if the specific flood would have been recorded if it had happened. If such determinations can be made with reasonable confidence, historical information is incorporated in the frequency analysis. In each year of the associated ungaged historical period, the lower and upper bounds of the flow interval are set to 0 and the magnitude of the specific flood, respectively; the lower and upper bounds of the perception threshold are set to the magnitude of the specific flood and infinity, respectively. If confident determination 
of nonexceedance cannot be made for a special-response record, the record is designated as an opportunistic peak flow and is excluded from the frequency analysis. Designation as an opportunistic peak-flow is not applied to extreme floods that are critical for reliable frequency analysis.

The WY-MT WSC use of best-available flow intervals and perception thresholds is considered to adhere to Bulletin $17 \mathrm{C}$ guidelines that specifically note that setting perception thresholds might involve substantial judgement. The bestavailable perception thresholds (and associated flow intervals) are based on actual recorded peak flows. Bulletin 17C specifically indicates that the bounds of the perception thresholds are independent of actual peak flows that have happened. However, in the absence of a prescribed rigorous perception threshold framework, the best-available perception thresholds are considered to reasonably accommodate the Bulletin $17 \mathrm{C}$ guidelines. Additional information on the approach for handling flow intervals, perception thresholds, and historical information is included in the section "Standard Procedures for Incorporating Historical Information."

Potential effects of using the best-available flow intervals and perception thresholds instead of a rigorous flow interval and perception threshold framework are difficult to quantify, but probably mostly relate to increased imprecision in quantification of error and uncertainty. In most cases the increased imprecision generally will be small and for most frequencyanalysis applications the confidence intervals about the frequency estimates are reasonably represented by the EMA estimates using best-available perception thresholds.

Paleoflood and botanical information also can be included as historical information within the EMA framework. Inclusion of paleoflood and botanical information can provide documentation of large floods within a long timeframe of potentially several hundreds to thousands of years. Such information can have large value in understanding the long-term context of recorded floods. Currently (2018), the WY-MT WSC has not sufficiently compiled and documented relevant paleoflood and botanical information for inclusion in frequency analyses for Montana streamgages.

Preparation of a strategic plan for better representing Montana peak-flow datasets within the EMA procedures of Bulletin $17 \mathrm{C}$ would be beneficial. The strategic plan would include developing protocols for defining lower bounds of perception thresholds based on specific stage markers and developing set protocols for monitoring the defined stage markers to trigger collection of important peak-flow records during ungaged periods. The strategic plan also would include efforts concerning the definition and application of the current (2018) best-available perception thresholds for handling historical adjustments that involve older (pre-1960) flood data and information. Such efforts might include formal electronic archival of relevant information that provides evidence that individual large floods were not exceeded during ungaged periods. The strategic plan also would include compilation of available paleoflood and botanical information and designing investigations to collect paleoflood and botanical information in areas where frequency analyses are complicated because of unusually large recorded floods. Finally, the strategic plan would describe efforts to identify individual peak flows with larger than typical uncertainty for appropriate handling using flow intervals.

\section{Selected Considerations for Peak-Flow Frequency Analysis}

Several considerations are important for understanding various issues relating to frequency analysis. Selected considerations are presented in the following sections "General Considerations" and "Peak-Flow Stationarity Considerations."

\section{General Considerations}

Bulletin $17 \mathrm{C}$ indicates that the frequency analysis methods of that report, which are based on analysis of the annual peak-flow series, are appropriate for estimating peak-flow quantiles for AEPs less than about 10 percent; that is, the use of the annual peak-flow series is recommended for larger, rarer events that have a 10 percent or smaller chance of being exceeded in any year. For smaller, more frequent events, secondary peak flows can occur within a water year that, although smaller than the maximum peak observed that year, are nevertheless events of interest. The secondary peak flows are not included in the annual peak-flow series. A frequency estimate based on the annual peak-flow series provides information only on the frequency at which the annual peak flows exceed specific values. The frequency at which any streamflow event exceeds specific values is not provided by the Bulletin 17C analysis. Consequently, caution should be exercised in use of peak-flow quantiles estimated using Bulletin 17C methods for AEPs greater than about 10 percent. Where information on the relationship between quantiles based on the annual peak-flow series and quantiles based on all streamflow events above a threshold is available, or information on minor floods defined by the annual peak-flow series is desired, the large AEP quantiles might still be useful. Thus, to provide potentially relevant information for frequency applications that consider AEPs greater than about 10 percent, the WY-MT WSC reports estimates of peak-flow quantiles for AEPs as large as 50 percent. Bulletin $17 \mathrm{C}$ indicates that analysis of the partial duration series (instead of the annual peak-flow series) might be appropriate for AEPs greater than about 10 percent.

In some cases, the WY-MT WSC reports results from multiple frequency analyses for a given streamgage because of uncertainties in interpretation of the data and variability in design criteria and potential risk tolerance among different frequency applications. Within the WY-MT WSC, known frequency applications include bridge and culvert design, floodplain mapping, dam design and analysis, and instream-flow water rights requests; other applications unknown to WY-MT 
WSC likely exist. The various frequency applications might focus on different parts of frequency curves and risk sensitivity can be substantially different among possible applications. For some scenarios, it might be important for a user to select the most conservative available frequency estimate. Various uncertainties in frequency analysis, including uncertain effects of regulation and uncertain applicability of frequencyadjustment methods, are important considerations in making informed decisions concerning the most appropriate frequency analysis for a particular application. Thus, in many cases, the WY-MT WSC impartially reports multiple frequency analyses to allow frequency-analysis users to make informed decisions relevant to their needs.

\section{Peak-Flow Stationarity Considerations}

Frequency analysis within the Bulletin 17 guidelines assumes temporal stationarity in the peak-flow datasets. Temporal stationarity requires that all of the data represent a consistent hydrologic regime within the same (albeit highly variable) fundamental climate system. In statistical terms, stationarity means that the probability characteristics of the observed peak-flow records are temporally consistent and are the same as those expected for future peak-flow records. In recent years, better understanding of long-term climatic persistence and concerns about climate change have prompted scrutiny of the concept of stationarity in frequency analysis and other hydrologic issues (Hirsch, 2011).

Researchers from USGS have analyzed hydrologic, tree ring, and paleoclimatic data in the north-central United States in relation to temporal characteristics of hydroclimate (Vecchia, 2008; Ryberg and others, 2014, 2015, 2016; Kolars and others, 2016; Hirsch and Ryberg, 2012). Among many findings, the researchers identified distinct hydroclimatic persistence characterized by alternating wet and dry periods dating back to the early 1700s (Vecchia, 2008; Ryberg and others, 2016). An important observation from the USGS research in the north-central United States is that before the start of systematic hydrologic data collection there were both wetter and drier hydroclimatic periods than have happened after the start of data collection (Karen R. Ryberg, U.S. Geological Survey, written commun., November 2016). Such research has relevance to frequency analysis for Montana streamgages and emphasizes the need for frequency-analysis methods that consider nonstationarity issues.

Sando and others (2016b) did an initial investigation of peak-flow trends and stationarity in Montana based on analysis of peak-flow records of 24 long-term streamgages; general conclusions were that the peak-flow records of most long-term streamgages could be reasonably considered as stationary for application of frequency analyses within a large statewide streamgage network. Distinct temporal trends were detected, but in all cases it was considered prudent to assume stationarity and include all available data in frequency analysis. However, Sando and others (2016b) also indicated that in some cases peak-flow trends can have substantial effects on frequency analyses and additional research is needed for better understanding and handling of potential nonstationarity issues.

Established methods are not yet available based on results from a national study for detecting and addressing changing hydroclimatic conditions in frequency analysis. The bestavailable methods still are based on presumption of stationarity and the WY-MT WSC considers frequency analysis of all available data to be the most prudent approach; however, uncertainties concerning possible effects of nonstationarity should be considered.

\section{Methods for Peak-Flow Frequency Analysis}

The current (2018) frequency-analysis methods used by the WY-MT WSC follow the Bulletin 17C guidelines that allow for informed-user adjustments to address special considerations for unusual peak-flow data. All frequency analyses are conducted using PeakFQv7.1. Frequency analyses are presented for 99 selected streamgages (fig. 1, table 3) to provide examples of the methods and considerations involved in applying the methods. Various information relating to frequency analysis for the example streamgages is presented in tables in a data release (McCarthy and others, 2018a) associated with this report. Description of the tables included in the separate data release is presented in table 4 . In addition to the tables, the separate data release (McCarthy and others, 2018a) also includes the frequency curves and associated information that are presented in separate worksheets for each frequency analysis; hyperlinks in the tables allow convenient access to the frequency curves and associated information. Further, the separate data release includes the input files to PeakFQv7.1, including the peak-flow data file and the analysis specification file that were used in the peak-flow frequency analyses.

The example streamgages were selected to represent all methods and considerations and to provide a large range in various streamgage characteristics, including contributing drainage area, regulation status, and length of peak-flow records. All hydrologic regions in Montana are represented by the example streamgages (fig. 1, table 3). For some of the example streamgages, aspects of the frequency analyses are discussed. Example streamgages not specifically discussed are presented for informational purposes.

\section{Data Collection, Compilation, and Pre-Analysis Data Combination and Correction}

Peak-flow frequency analyses reported by the WY-MT WSC are based on peak-flow records from USGS streamgaging operations, including continuous streamflow operations and CSG operations. Methods for USGS streamgaging 


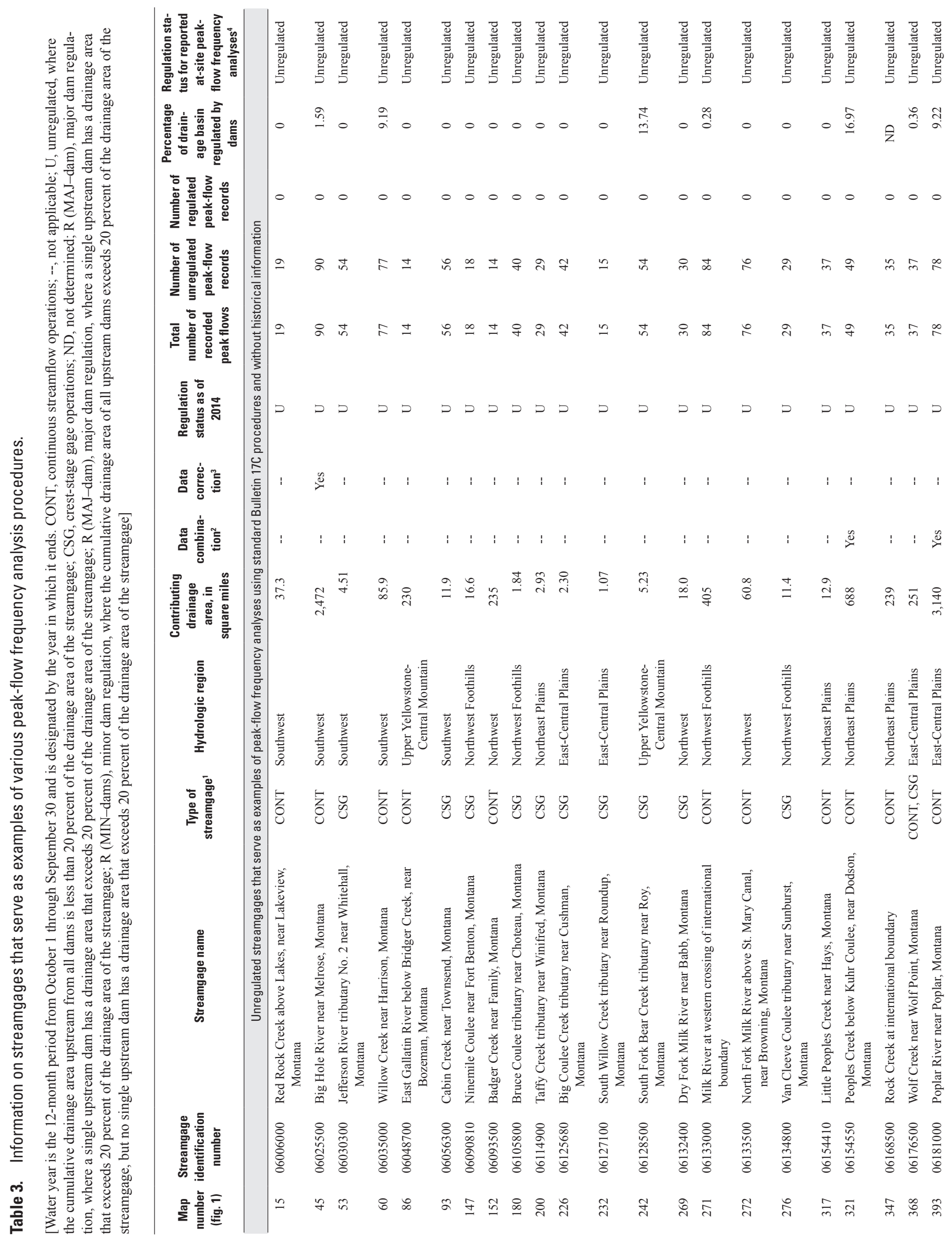




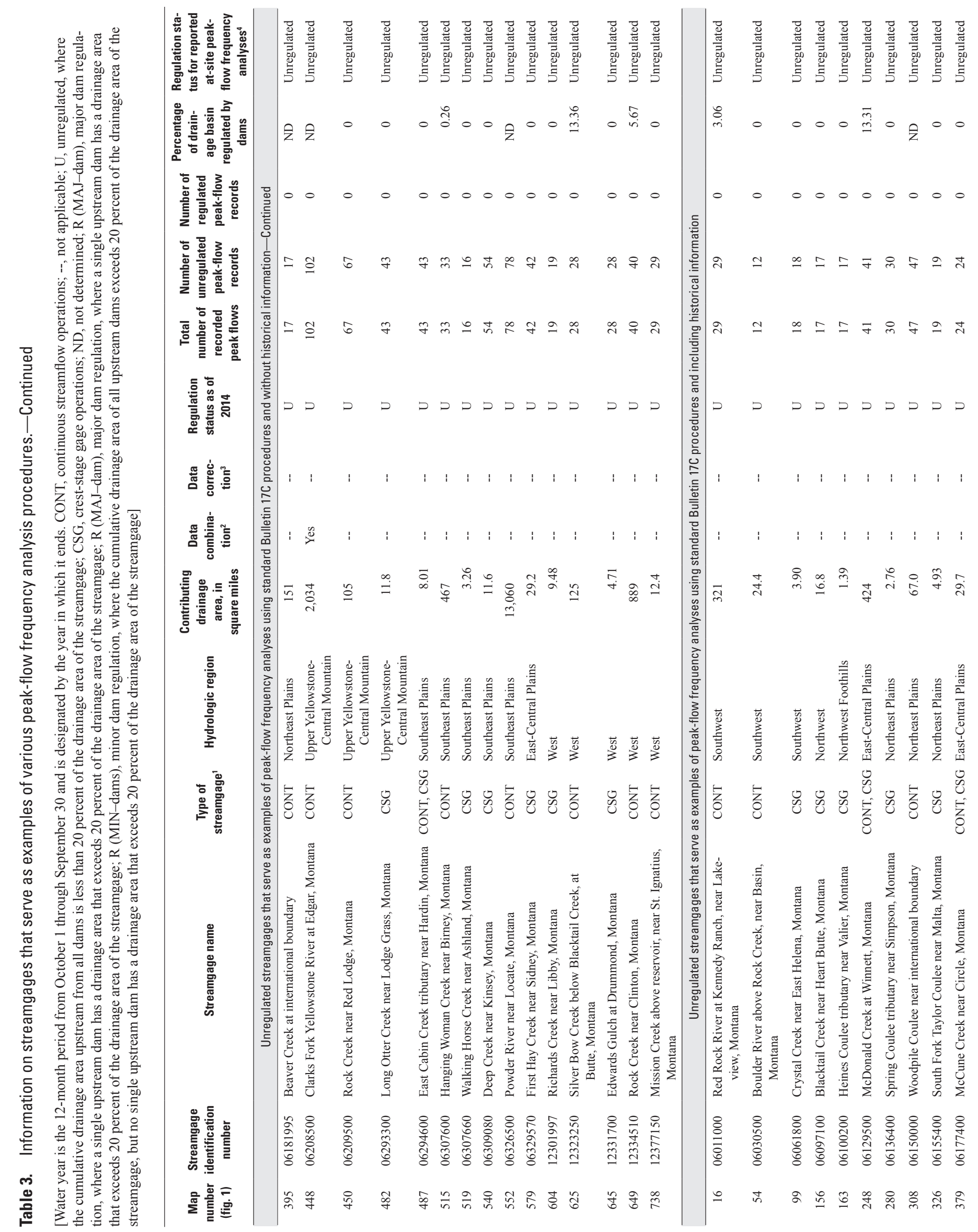




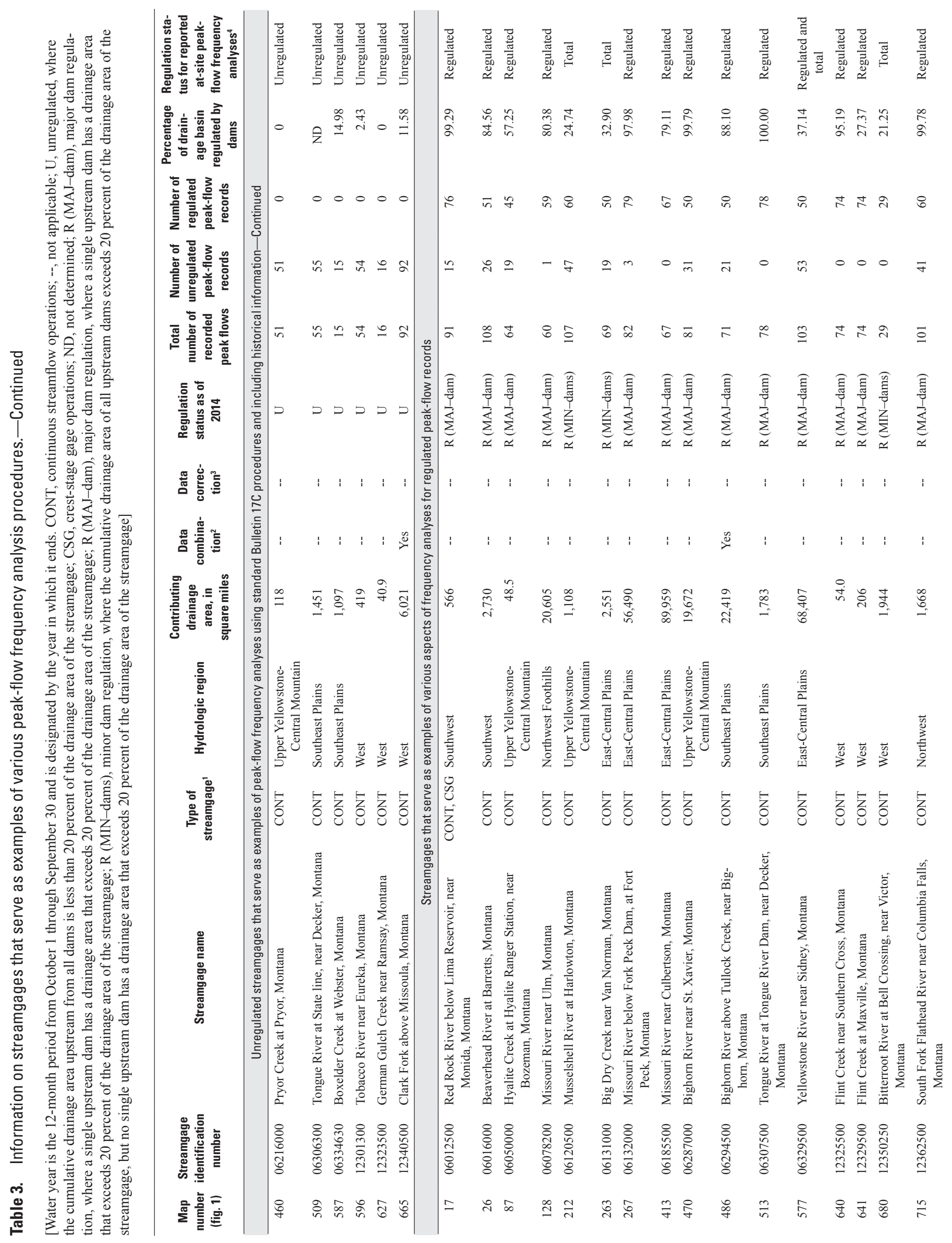




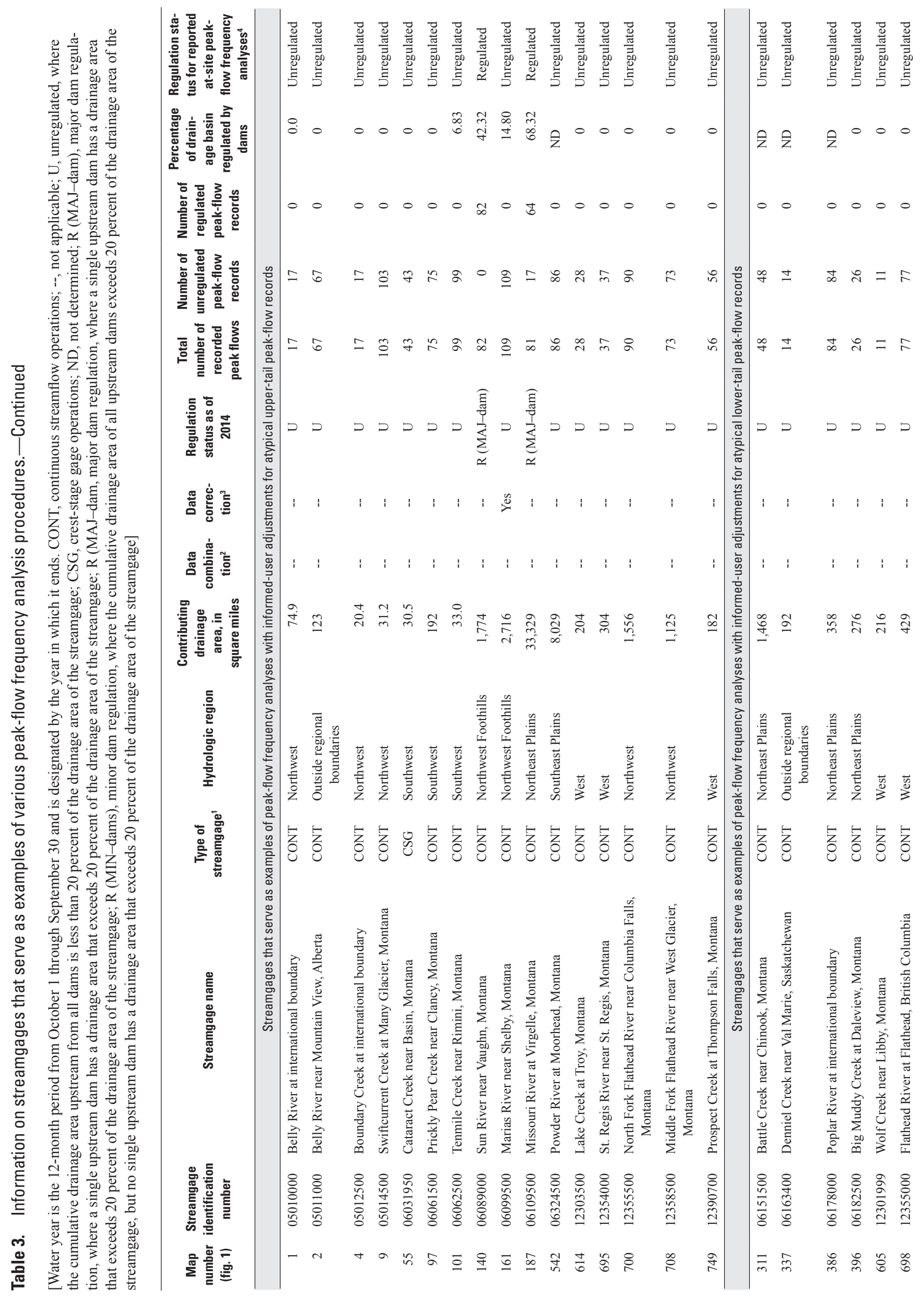


- 8 के

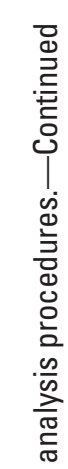

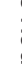

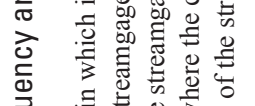

व

उ.

훈

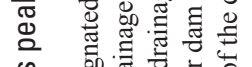

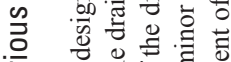

은

पे 당 है है

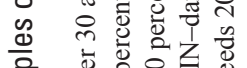

言 总完之。

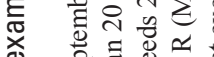

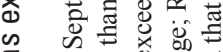

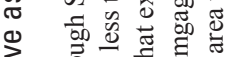

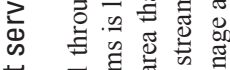

可 氜

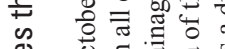

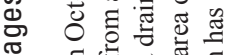

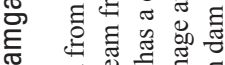

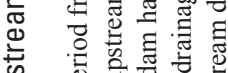

ᄃ

들

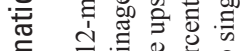

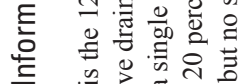

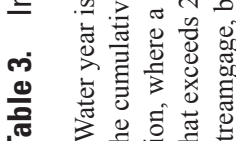

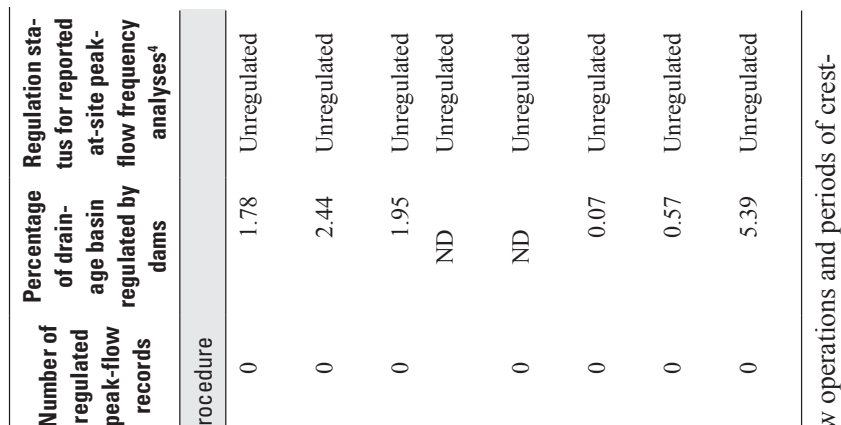

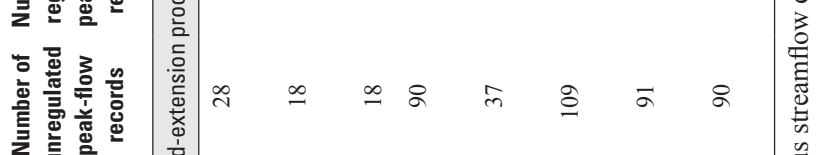

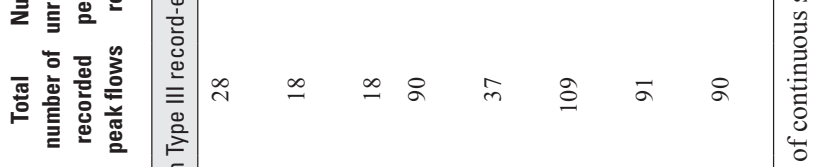

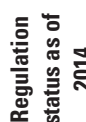

畄离言

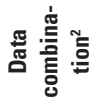

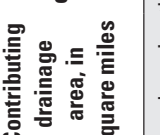

흘

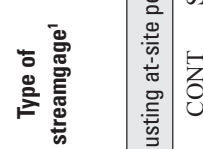

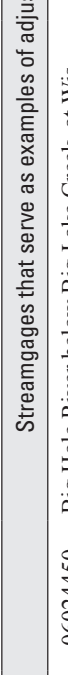

III

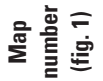

帘

意

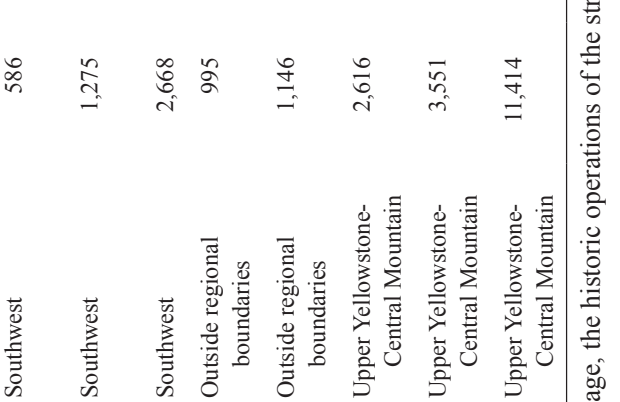

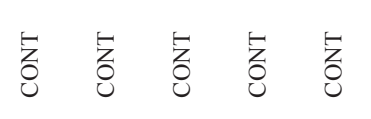

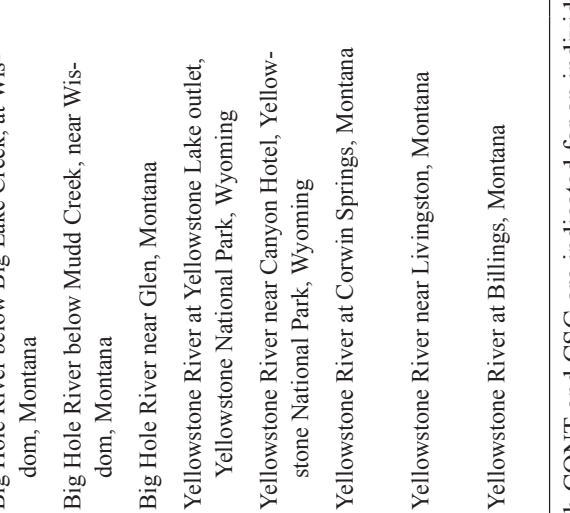

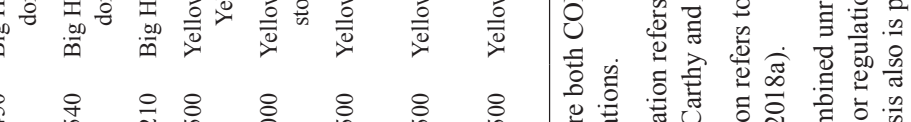

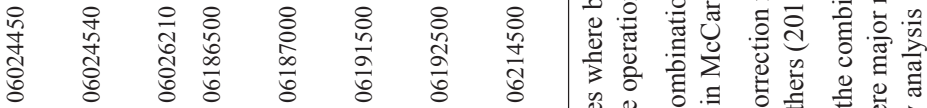

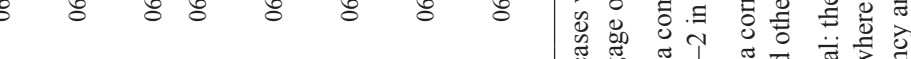

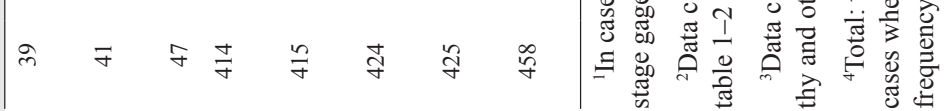


Table 4. Description of tables in the data releases (McCarthy and others, 2018a, b, and c) associated with this report.

\begin{tabular}{cl}
\hline Table & Title \\
\hline Table 1-1 & Information on streamgages for which peak-flow frequency analyses are reported. \\
Table 1-2 & Information on data combination by combining records of multiple streamgages. \\
Table 1-3 & Information on data correction of specific peak-flow records. \\
Table 1-4 & $\begin{array}{l}\text { Documentation on analytical procedures for peak-flow frequency analyses. } \\
\text { Table 1-5 }\end{array}$ \\
$\begin{array}{c}\text { Documentation regarding incorporating historical information in applicable at- } \\
\text { site peak-flow frequency analyses. }\end{array}$ \\
Table 1-6 & $\begin{array}{c}\text { Documentation regarding the Maintenance of Variance Extension Type III } \\
\text { (MOVE.3) record-extension procedure for selected streamgages. }\end{array}$ \\
Table 1-7 & $\begin{array}{l}\text { Peak-flow frequency results. } \\
\text { Table 1-8 }\end{array}$ \\
\hline
\end{tabular}

operations are described by Rantz and others (1982), Sauer and Turnipseed (2010), and Turnipseed and Sauer (2010).

Among the 725 streamgages reported in Sando and others (2016a), most represent continuous streamflow operations, which consist of continuous stage instrumentation and frequent periodic site visits with discharge measurements. The periodic discharge measurements are used to develop stagedischarge rating curves for reporting daily mean streamflows and annual peak flows.

Many (more than 300) Montana streamgages represent CSG operations, which consist of one or more vertical pipes that measure high-water marks. The CSG operations involve less frequent periodic site visits with discharge measurements but provide sufficient information for reporting of annual peak flows. Many CSGs are in remote locations on ephemeral streams that can have extended periods of zero streamflow; acquiring sufficient discharge measurements to produce a suitable stage-discharge rating curve can be difficult. In some cases, quantification of annual peak flows at CSGs is based on indirect measurements using theoretical culvert computations or step-backwater computations (Davidian, 1984).

Peak-flow frequency analyses reported by the WY-MT WSC are based on peak-flow records retrieved from the NWISWeb PFF. In some cases, the raw data retrieved from the NWISWeb PFF are combined or manually corrected before analysis to improve frequency analyses.

\section{Pre-Analysis Data Combination}

Data combination refers to combining the nonconcurrent peak-flow records of two or more closely located streamgages on the same channel, generally with drainage areas that differ by less than about 5 percent. The combined peak-flow records are assigned to the streamgage with the most recent data and the resulting frequency analysis represents a larger range in hydroclimatic conditions than separate analyses on the records of the individual streamgages. Five example streamgages affected by data combination are indicated in table 3 with additional details presented in table 1-2 in McCarthy and others (2018a). The methods for data combination are consistent with the methods used in previous reporting of frequency analyses for Montana streamgages (Parrett and Johnson, 2004; Sando and others, 2016a).

Data combination usually consists of combining the records of two or more streamgages that have been operated by the USGS following documented procedures for data collection. In unusual, rare cases the WY-MT WSC will combine the records from streamgages operated by other agencies with the records of USGS streamgages. Such cases are governed by special needs for critical information to provide reliable frequency for a given USGS streamgage.

\section{Pre-Analysis Data Correction}

Data correction refers to manual substitution or exclusion of peak-flow records such that the data retrieved from the NWISWeb PFF are altered before frequency analysis. In rare cases, data correction by manual substitution is needed to provide reliable frequency analyses. For example, the June 1964 peak flow for Marias River near Shelby, Montana (streamgage 06099500; map number 161; fig. 1) was affected by an upstream dam break; an estimated "unaffected" value of 150,000 cubic feet per second $\left(\mathrm{ft}^{3} / \mathrm{s}\right)$ was substituted for the recorded 241,000 ft $3 / \mathrm{s}$ based on investigation of the dam break (Charles Parrett, U.S. Geological Survey, written commun., June 2000). The methods for data correction by manual substitution are consistent with the methods used in previous reporting of frequency analyses for Montana streamgages (Parrett and Johnson, 2004; Sando and others, 2016a). 
In rare cases, individual peak flows are known to be affected by atypical events, such as dam breaks or seismic events, and data correction by exclusion of individual peak flows is necessary. Occasionally, an individual peak flow was collected outside of the systematic record during specialresponse events, but the peak flow was of insufficient magnitude to confidently determine nonexceedance during an ungaged period. In this case, the peak flow is designated as an opportunistic peak and excluded from the frequency analysis. Specific information on data correction for affected example streamgages is presented in table 1-3 in McCarthy and others (2018a).

\section{Determination of Regulation Status of Streamgages}

Addressing the effects of reservoir regulation on frequency analysis is critical because 102 of the 725 streamgages considered by Sando and others (2016a) have frequency analyses affected by major dam regulation. Similar to Bulletin 17B, Bulletin 17C indicates that the guidelines do not apply to streamgages substantially affected by reservoir regulation. However, frequency analyses are needed for regulated streamgages and in most cases, with proper handling of the datasets, the Bulletin 17 guidelines can be applied to produce reliable frequency analyses (U.S. Geological Survey, 2012; Advisory Committee on Water Information, 2002).

A geospatial database of 2,817 dams in Montana that is used to define the regulation status for Montana streamgages is described by McCarthy and others (2016), who also defined regulation-classification criteria. A streamgage is considered regulated if the cumulative drainage area of all upstream dams exceeds 20 percent of the streamgage drainage area. If the drainage area of a single upstream dam exceeds 20 percent of the streamgage drainage area, the streamgage is classified as having major dam regulation. Otherwise, the streamgage is classified as having minor dam regulation. For cases where a large diversion canal is known to be located on the channel upstream from a streamgage, the streamgage is classified as having major canal regulation. A streamgage is considered to be unregulated if the cumulative drainage area upstream from all dams is less than 20 percent of the streamgage drainage area and no large diversion canals are upstream from the streamgage.

Given various uncertainties in confident classification of regulation status, in a few cases the WY-MT WSC reports multiple frequency analyses for streamgages affected by major regulation. For all major-regulation streamgages with peakflow records after the start of regulation, a frequency analysis for the regulated period is reported. In some cases, majorregulation streamgages also have peak-flow records before the start of regulation. In a few of such cases, the percent of the streamgage basin that is upstream from the reservoir is less than about 50 percent and a frequency analysis for the total period of record that includes pre- and post-regulation peak flows also is provided. The "total" frequency analysis is provided in recognition of uncertainties in the regulation classification with respect to specific frequency-analysis applications; that is, the "total" frequency analysis generally will be the most conservative analysis and might be more appropriate for protection of life and property.

For streamgages classified as having minor dam regulation, frequency analysis is conducted on the total period of record, which might have been in the period before the construction of minor dams, in the period after the construction of minor dams, or spanning both. Thus, for frequency applications, streamgages classified as having minor dam regulation essentially are treated as unregulated. Generally, multiple small impoundments contribute to the minor dam regulation classification and the effects of these dams on streamflow characteristics are poorly understood. Further, the number of small impoundments represented in the WY-MT WSC dams database is only a small subset of the total number of small impoundments in Montana (McCarthy and others, 2016). The dams that contribute to the minor dam regulation classification generally have substantially less storage capacity than the dams that contribute to the major dam regulation classification, and currently (2018) little documentation is available on the operations, associated water-use activities, and primary purposes of the minor regulation dams. However, some research (for example, Culler and Peterson, 1953; Frickel, 1972; Parrett, 1986; Womack, 2012; Ayalew and others, 2017) has determined that the cumulative effect of small impoundments can have substantial effects on various streamflow characteristics including peak flows. Bulletin $17 \mathrm{C}$ also recognizes that the cumulative effect of small impoundments on frequency analyses can be substantial. Although available data do not allow confident determination of the effects of small impoundments on frequency analyses, the WY-MT WSC considers it prudent to inform frequency-analysis users of the occurrence of small impoundments and acknowledge potential effects on frequency analyses. Future research might allow better handling for minor dam regulation datasets.

The WY-MT WSC classification system for defining regulation is not reflected in the NWISWeb PFF. The NWISWeb PFF has peak-flow qualification codes for identifying potential regulation effects, with a code equal to 5 indicating that the peak flow is affected to an unknown degree by regulation or diversion and a code equal to 6 indicating that the peak flow is affected by regulation or diversion (U.S. Geological Survey, 2009). With respect to regulation effects, the peak-flow qualification codes in the NWISWeb PFF for Montana streamgages are inconsistent and do not represent detailed investigations of regulation effects. Presumably, individuals responsible for maintaining the NWISWeb PFF for Montana streamgages have recognized uncertainties in distinguishing between code values of 5 and 6 and have been reluctant to hard code decisions into the permanent electronic database. Thus, the peak-flow qualification codes of 5 and 6 in the NWISWeb PFF cannot be relied upon with respect to accurate representation of regulation status. Instead, information presented in the 
data-release tables (McCarthy and others, 2018a) accurately represents the regulation status determinations of the WY-MT WSC.

The WY-MT WSC recognizes the need for additional research on regulation effects in relation to frequency analysis. The criteria of the WY-MT WSC for defining regulation status of streamgages in Montana is based solely on affected drainage area and does not account for storage capacity characteristics of the dams or other regulating factors such as stream diversions. Storage capacity data are included in the geospatial database of dams (McCarthy and others, 2016). More clearly defining regulation effects on streamflow characteristics by incorporating storage capacity information considered in relation to streamflow characteristics will be important in future studies of regulation effects. Better identification and documentation of small impoundments throughout Montana also will be important in future studies of regulation effects. Furthermore, datasets for irrigation diversions currently (2018) are not readily available at sufficient scale and coverage for assessing their effects on frequency analyses within a large statewide streamgage network. Compilation of a statewide dataset of locations and capacities of irrigation canals would be important for better definition of regulation effects on streamflow characteristics. For example, a strategic plan for better representing Montana peak-flow datasets within the Bulletin 17C framework would be beneficial. Compiling and developing relevant information for confident determination of regulation status would be a priority within the strategic plan, which would include appropriate coding of regulation status in the NWISWeb PFF.

\section{Procedures for At-Site Frequency Analyses}

An "at-site frequency analysis" refers to an analysis conducted on the recorded peak-flow data for a specific streamgage. Procedures addressed include (1) handling of broken-record datasets, (2) standard procedures for implementing the Bulletin 17C guidelines, and (3) various informed-user adjustments based on hydrologic judgement that might be needed to address special circumstances.

\section{Handling of Broken-Record Datasets}

Frequency analysis requires that peak-flow data are a random sample of events representative of the population of future events. Typically, systematic peak-flow records meet the randomness requirement. Systematic records are collected at regular, prescribed intervals under a defined protocol, generally during multiple consecutive years. Breaks in the systematic record occur when a streamgage is discontinued and then later reactivated, which results in multiple segments of systematic record. If the multiple segments represent a consistent hydrologic regime, they can be analyzed as a continuous record, but appropriate perception flow intervals and thresholds must be assigned to the ungaged periods. In the Montana streamgage network, broken records are common; about one-half of the 725 streamgages presented in Sando and others (2016a) have one or more breaks in the peak-flow records. For most Montana streamgages with broken records, multiple segments of systematic record represent consistent hydrologic regimes and are analyzed as continuous records. In cases of no knowledge of peak-flow conditions in the ungaged periods between the systematic-record segments, the lower and upper perception thresholds are both set to infinity. In cases of historical adjustments having application to the ungaged periods, perception thresholds are defined as described in the section "Standard Procedures for Incorporating Historical Information."

\section{Standard Procedures for Implementing the Bulletin 17C Guidelines}

Standard procedures of the WY-MT WSC for implementing the Bulletin $17 \mathrm{C}$ guidelines include (1) the use of the EMA analysis for fitting the log-Pearson Type III distribution, incorporating historical information where applicable; (2) the use of weighted skew coefficients (based on weighting at-site station skew coefficients with generalized skew coefficients from the Bulletin 17B national skew map); and (3) the use of the MGBT for identifying PILFs. Specific information regarding application of the standard procedures is presented in the following sections: "Standard Procedures for Weighted Skew Coefficients," "Standard Procedures for Handling Potentially Influential Low Flows," and "Standard Procedures for Incorporating Historical Information." There are 37 example streamgages that represent standard procedures with no historical information and 16 example streamgages that represent standard procedures with historical information (table 3).

Setting flow intervals and perception thresholds for some CSGs involves special considerations. The special considerations relate to issues primarily affecting peak flows near the extreme lower tail of the frequency distribution, as discussed in the section "Standard Procedures for Setting Flow Intervals and Perception Thresholds for Crest-Stage Gages."

\section{Standard Procedures for Weighted Skew Coefficients}

The standard procedures for determining the skew coefficients involve weighting the at-site station skew coefficient with a generalized skew coefficient from the Bulletin 17B national skew map. The at-site station skew coefficient can have somewhat large uncertainty in even modest length systematic records (Griffis and Stedinger, 2007) that can be stabilized by weighting with regional skew information. Parrett and Johnson (2004) analyzed skew coefficients in Montana and concluded that the differences between the generalized skew coefficients from the Bulletin 17B national skew map and the regional skew coefficients from their analysis were "small and probably not significant." Thus, Parrett and Johnson (2004) determined that the generalized skew coefficients from the Bulletin 17B national skew map were appropriate 
for frequency analysis and calculated the standard error of the Bulletin 17B national skew map to be 0.64 for Montana streamgages.

Bulletin $17 \mathrm{C}$ indicates that regional skew estimates from the Bulletin 17B national skew map are not recommended for frequency analysis and that regional skew estimates should be developed using the Bayesian Weighted Least Squares/ Bayesian Generalized Least Squares (BWLS/BGLS) method (Veilleux and others, 2011). A BWLS/BGLS regional skew study that provides updated BWLS/BGLS regional skew estimates for all of Montana could improve estimates of peakflow quantiles when the BWLS/BGLS regional skew estimates are applied to WY-MT WSC frequency analysis methods described in this report. Currently (2018), for consistent application to all Montana streamgages, the WY-MT WSC considers the best-available method for determining weighted skew coefficients to be the use of generalized skew coefficients from the Bulletin 17B national skew map with a standard error of 0.64 as determined by Parrett and Johnson (2004). For the example streamgages, information on the analysis skew coefficients (either weighted skew coefficients for standard procedures or at-site station skew coefficients for informeduser adjustments) is presented in table 1-4 of McCarthy and others (2018a).

\section{Standard Procedures for Handling Potentially Influential Low Flows}

In frequency analysis, low-lying data points can exert a large distorting effect on the fitted frequency curve (Advisory Committee on Water Information, 2002). Bulletin 17B guidelines used the Grubbs-Beck test (Grubbs and Beck, 1972) to identify low outliers and a conditional probability adjustment to handle the low outliers, but the procedures were ineffective in appropriate identification and handling of low-lying data points. In relation to Bulletin 17B, the Bulletin 17C use of the MGBT (Cohn and others, 2013) for identifying PILFs and the EMA procedures for handling the PILFs provide for more effective identification and handling of low-lying data points. Among the example streamgages, there are many cases of the MGBT identifying PILFs that are censored within the EMA procedures as indicated in table 1-4 of McCarthy and others (2018a). Example streamgages with MGBT PILF censoring include 06030300, 06125680, 06128500, 06176500, 06294600, 06307600, 12334510, and many others (map numbers $53,226,242,368,487,515$, and 649 , respectively; fig. 1 ).

\section{Standard Procedures for Incorporating Historical Information}

As discussed in the section "The Expected Moments Algorithm Procedures in Relation to Montana Peak-Flow Datasets," the standard procedures for incorporating historical information involve definition and application of best-available flow intervals and perception thresholds for frequency analyses that include systematic records, historical peak flows, and ungaged historical periods. The current (2018) standard procedures for incorporating historical information reflect application of the Bulletin $17 \mathrm{C}$ guidelines within the constraints of the Montana peak-flow datasets and best-available perception thresholds (and associated flow intervals).

There are 16 example streamgages that represent standard procedures for incorporating historical information (table 3 ). Also, historical information was incorporated in the frequency analyses for 18 other example streamgages that are included in the other example designations (such as regulated peakflow records, atypical upper-tail peak-flow records, atypical lower-tail peak-flow records, and MOVE.3 record extension). For all of the frequency analyses that incorporate historical information, the specific aspects of the handling of the historical information is included in table $1-5$ of McCarthy and others (2018a); that is, for each historical-information frequency analysis, the following data are presented: (1) the specific large peak flow(s) used to estimate flow intervals and perception thresholds for ungaged historical periods; and (2) the ungaged historical period associated with each specific large peak flow. In the frequency curve worksheets for each historical-information frequency analysis, the assigned perception thresholds for the ungaged historical periods are shown.

\section{Standard Procedures for Setting Flow Intervals and Perception Thresholds for Crest-Stage Gages}

Setting perception thresholds for some CSGs involves special considerations, which relate to issues primarily affecting peak flows near the extreme lower tail of the frequency distribution. Generally, the handling of peak flows near the extreme lower tail of the frequency distribution has little effect on frequency analyses; the low peak flows typically are either censored by PILF thresholds or have small influence in determining the distributional parameters of the log-Pearson Type III distribution.

The gage base of an individual CSG might not be low enough to document the zero-flow condition or the lowest possible peak flow. Thus, the lower and upper perception thresholds might be considered to be from the gage base to infinity, respectively; however, several factors potentially complicate precise definition of the perception thresholds (and associated flow intervals) for CSGs. Throughout the history of the Montana streamgage operations, there have been various approaches for handling quantification of peak flows that were below the gage base. In many cases, hydrographers specifically noted that there was no evidence of streamflow in the stream channel throughout an individual year and recorded an annual peak flow of zero. In some cases of known nonzero streamflow below the gage base, hydrographers measured a negative gage height (that is, below the gage base) and either estimated or measured the annual peak flow associated with the recorded negative gage height. In some cases of known nonzero streamflow below the gage base, hydrographers only noted that the streamflow never reached the gage base and sometimes estimated an annual peak flow or sometimes recorded an annual peak flow equal to the gage base with a 
qualification code of 4 indicating "less than." Thus, in some cases there is uncertainty in the understanding of the sampling properties in the range of peak flows from zero to the gage base. The representation of annual peak flows below the gage base in the NWISWeb PFF reflects the described various approaches and is considered to provide the best-available information on the sampling properties.

A rigorous approach to the perception threshold framework of EMA would require precise and consistent documentation of the gage base throughout the period of record; however, the variability in the handling of annual peak flows that were below gage base in the Montana streamgage operations currently (2018) does not allow application of the rigorous approach. Currently (2018), the WY-MT WSC approaches the issue of setting perception thresholds for CSGs with consideration that the handling of peak flows near the extreme lower tail of the frequency distribution generally has little effect on frequency analyses. The representation of annual peak flows below the gage base in the NWISWeb PFF is considered to be reasonably accurate. There are 27 example streamgages that represent CSG operations during part or all of their periods of record (table 3).

\section{Informed-User Adjustments to Bulletin 17C Guidelines}

For some streamgages, the peak-flow records are not well represented by the standard procedures and require informeduser adjustments. The specific characteristics of peak-flow records addressed by informed-user adjustments include (1) regulated peak-flow records, (2) atypical upper-tail peakflow records, and (3) atypical lower-tail peak-flow records. In all cases, the informed-user adjustments use the EMA fit of the log-Pearson Type III distribution. The deviations from the standard procedures in all cases involve selection of the at-site station skew coefficient instead of the weighted skew coefficient, definition of a manual PILF threshold instead of the standard MGBT PILF threshold, or both. Frequency analyses based on informed-user adjustments are specifically noted in table 1-4 of McCarthy and others (2018a) in the column "Primary reason for deviation from standard Bulletin 17C procedures."

\section{Adjustments for Handling Regulated Peak-Flow Records}

The Bulletin 17C guidelines do not apply to peak-flow records affected by reservoir regulation. Regulated peak-flow records might not be appropriately represented by the logPearson Type III distribution. However, frequency analyses are needed for regulated streamgages and in most cases, with proper handling of the datasets, the Bulletin 17 guidelines can be applied to produce reliable frequency analyses (U.S. Geological Survey, 2012; Advisory Committee on Water Information, 2002). In essence, application of Bulletin 17 guidelines to regulated peak-flow records requires more review and care than unregulated peak-flow records.
Classification of regulation status for Montana streamgages is described in the section "Determination of Regulation Status of Streamgages." The following discussion applies to frequency analysis of peak-flow records affected by major regulation.

Initial frequency analyses are conducted using standard procedures and the preliminary frequency curves are evaluated. Additional frequency analyses might then be conducted using the at-site station skew coefficient with no weighting, a manual PILF threshold, or both. For a given streamgage, final selection of the most appropriate frequency analysis is based on several considerations, including (1) the fit of the frequency curve in relation to the peak-flow plotting positions (especially in the range of AEPs from 50 to 1 percent); (2) the percent of the drainage area affected by regulation; (3) the maximum storage capacity of the dam in relation to the median peak flow of the streamgage; and (4) in some cases, maintaining consistency in analytical approach among regulated streamgages with similar hydrologic characteristics. For streamgages with greater than 80 percent of drainage area affected by regulation, the at-site station skew coefficient is used in nearly all cases.

Use of the at-site station skew coefficients reflect a general assumption that regulation effects can result in peakflow characteristics that are not represented in generalized skew coefficients developed from unregulated streamgages; thus, use of the weighted skew coefficient can be inappropriate. In some cases, regulation effects can result in abnormal slope changes in the lower tail of the frequency distribution that are not detected by the MGBT; these cases are addressed by applying a manual PILF threshold on a case-by-case basis.

In a few cases, the WY-MT WSC reports multiple frequency analyses for streamgages affected by major regulation. For all major-regulation streamgages with peak-flow records after the start of regulation, a frequency analysis for the regulated period is reported. In some cases, majorregulation streamgages also have peak-flow records before the start of regulation. In a few of such cases, the percent of the streamgage basin that is upstream from the reservoir is less than about 50 percent and a frequency analysis for the total period of record that includes pre- and post-regulation peak flows also is provided. In such cases, the "total" frequency analysis is provided in recognition of uncertainties in the regulation classification with respect to specific frequency-analysis applications. In many cases, the "total" frequency analysis will be the most conservative analysis and might be more appropriate for protection of life and property.

Frequency curves for Flint Creek near Southern Cross, Montana (streamgage 12325500; map number 640; fig. 1) indicate differences between standard procedures (fig. $3 A$ ) and adjustments for handling regulated peak-flow records (fig. $3 B$ ). Frequently, regulated peak-flow records will exhibit an S-shaped pattern in the peak-flow plotting positions, which is the case for streamgage 12325500 (fig. 3). The MGBT appropriately identifies PILFs and effectively censors the lower 


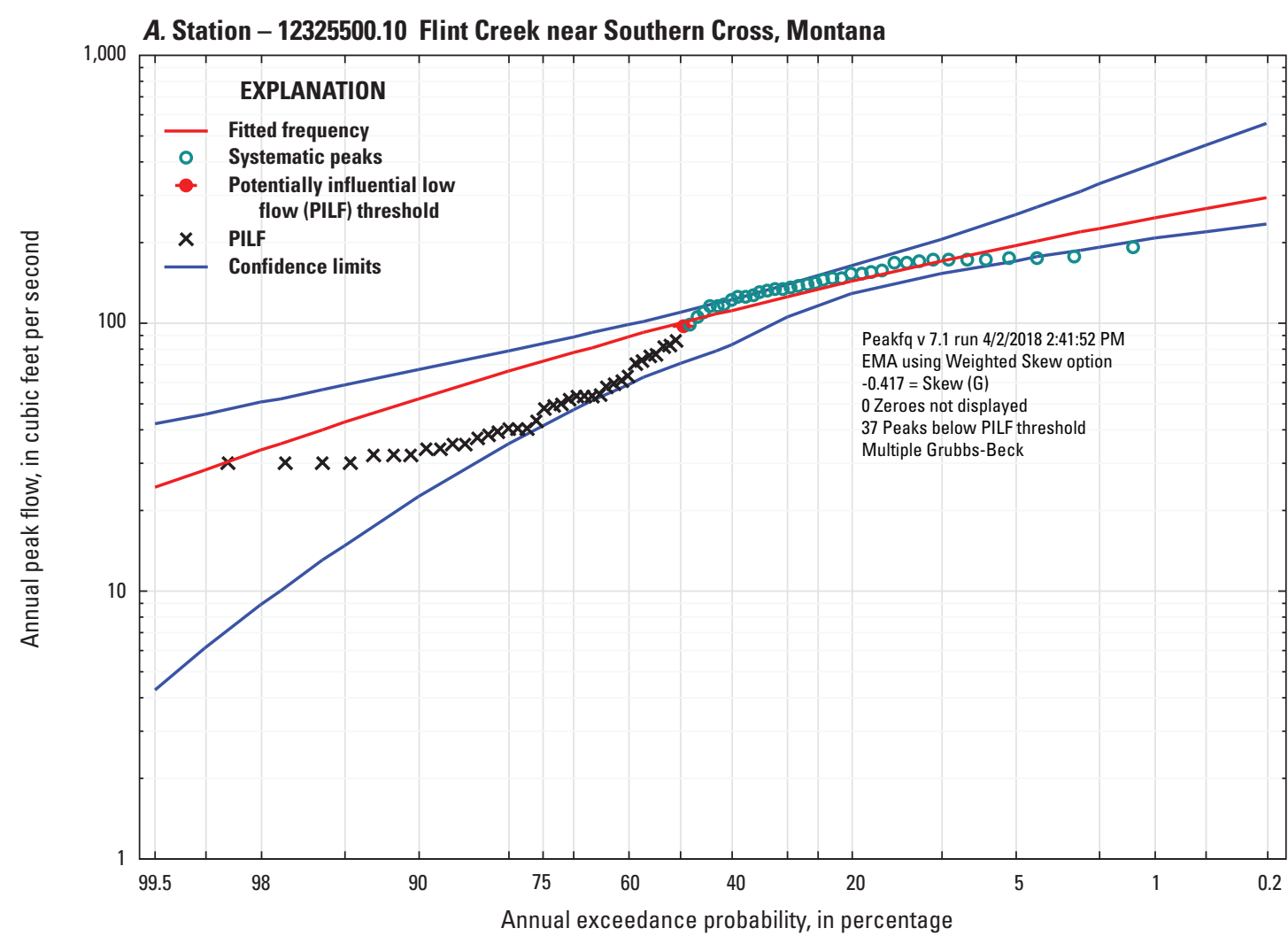

B. Station - 12325500.10 Flint Creek near Southern Cross, Montana

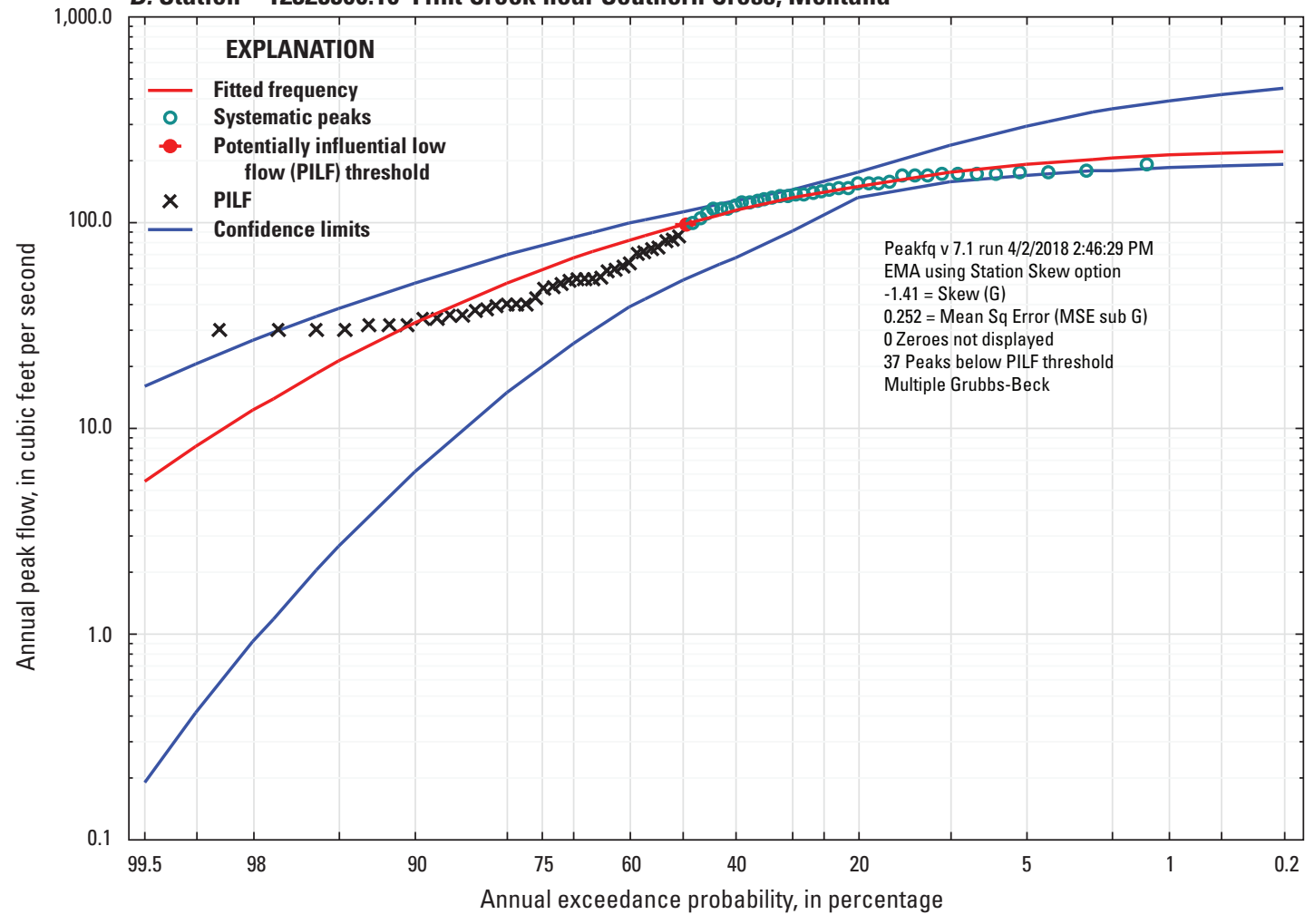

Figure 3. PeakFQv7.1 output-Peak-flow frequency curves for Flint Creek near Southern Cross, Montana (streamgage 12325500). $A$, Frequency curve using standard procedures; $B$, Frequency curve using informeduser adjustments for handling regulated peak-flow records. 
part of the S-shaped pattern; however, the use of the weighted skew coefficient in standard procedures is not appropriate for the regulated condition and results in the frequency curve being above the peak-flow plotting positions (fig. $3 A$ ) in the upper tail of the frequency curve. The use of the at-site station skew coefficient in the adjustments for regulated peak-flow records provides appropriate fit of the peak-flow plotting positions (fig. 3B).

There are 16 example streamgages that indicate various aspects of frequency analyses for regulated peak-flow records (table 3 ). The regulation status and the percent of the streamgage drainage basin affected by regulation are presented in table 3. The unregulated (pre-regulation) and regulated periods of record for the streamgages are included in table 1-1 of McCarthy and others (2018a). In cases that the at-site station skew coefficient or a manual PILF is used in a frequency analysis for a streamgage affected by major regulation, indication is provided in the column "Primary reason for deviation from standard Bulletin $17 \mathrm{C}$ procedures" in table $1-4$ of McCarthy and others (2018a).

\section{Adjustments for Handling Atypical Upper-Tail Peak-Flow Records}

In the Montana peak-flow datasets, the primary factor contributing to atypical upper-tail peak-flow records is mixed populations of peak-flow events. Peak-flow records for all Montana streamgages include or have the potential to include mixed populations of peak-flow events as described in the Bulletin 17 series. Major drivers of Montana peak-flow events include snowmelt, rainfall, and snowmelt with rainfall. Within the major drivers, specific natural conditions including ice jams and releases, unusually rapid snowmelt (for example, during warm, downslope wind [Chinook] events ), and frozensoil conditions can amplify flood events. Most Montana peak-flow datasets have the appearance of homogeneity and effectively can be treated as coming from a single population without consideration of mixed-population effects. However, in some cases there is clear appearance of nonhomogeneity because of mixed-population effects, wherein large peak flows in the upper tail of the frequency distribution depart substantially from the main body of the remaining data. Mixed-population issues present challenges in frequency analysis for Montana streamgages as discussed in Sando and others (2016a).

The combination of snowmelt peak flows and snowmeltwith-rainfall peak flows accounts for most nonhomogeneous mixed-population peak-flow datasets. For many Montana streamgages with mixed-population characteristics, the largest floods have resulted from intense May or June rainfall that occurred near the peak of snowmelt runoff (as described in the section "Brief Overview of Unusually Large Floods in Montana"). The large snowmelt-with-rainfall peak flows can be substantially elevated above the main body of peak flows that typically represent snowmelt runoff. The described large snowmelt-with-rainfall floods are most typical in areas near or adjacent to the Continental Divide and the Rocky Mountain
Front in the Northwest and Northwest Foothills hydrologic regions, and parts of the Southwest hydrologic region (fig. 1). For some mixed-population streamgages in interior mountain areas of western Montana (primarily in the West hydrologic region; fig. 1), unusual cool-season intense rainfall events caused by atmospheric rivers can produce large snowmeltwith-rainfall floods (as described in the section "Brief Overview of Unusually Large Floods in Montana"). Flooding associated with the cool-season floods can be amplified by frozen-soil conditions and ice-jam releases (U.S. Army Corps of Engineers, 1991, 1998; Vogel and Stedinger, 1984, White, 2004), which are factors sometimes associated with breakup events that more typically occur in late winter and early spring.

The Bulletin 17 series provides guidance on handling mixed-population datasets. In cases that mixed-population events can be segregated based on distinct physical processes, separate frequency analyses can be conducted on each population and the frequency curves are combined using joint probability theory (U.S. Army Corps of Engineers, 1982). In cases that the mixed-population events cannot be segregated based on distinct physical processes, the data are treated as a single population using standard procedures. The Bulletin 17 series guidelines for mixed-population analyses present problems for broad application to Montana datasets because of difficulties in (1) confident segregation of peak flows based on distinct physical processes; (2) sufficient representation of different event types to allow determination of separate frequency analyses for each of the distinct populations; and (3) producing appropriate frequency results when the entire peak-flow record of a streamgage is treated as coming from a single population without appropriate adjustments. More detailed discussion of mixed-population issues in Montana is presented in Sando and others (2016a). A particular problem with the Bulletin 17 guidelines is lack of an objective procedure to assist in identifying nonhomogeneity in mixed-population datasets. Intuitively, some formulation of the MGBT applied to the upper tail of the frequency distribution might provide useful information to assist frequency analysts in handling mixed-population datasets.

Sando and others (2016a) considered various approaches for handling mixed-population issues for Montana streamgages and described a selected approach that involves analysis of the entire peak-flow record of a streamgage (with no segregation of different events) with the use of the at-site station skew coefficient and, in some cases, a manual PILF threshold. In an effort to provide general consistency among streamgages in identifying mixed-population datasets and applying the selected approach, the following criteria were considered: (1) in the peak-flow plotting positions, at least two large peak flows are substantially elevated above the main body of peak flows and the elevated peak flows are known to be affected by large snowmelt-with-runoff events; (2) in the probability plots, a distinct upward break in slope is apparent in the upper tail of the frequency distribution, typically in the range of AEPs from about 20 to 2 percent; (3) in the 
probability plots, a distinct downward break in slope is apparent in the lower tail of the frequency distribution, typically in the range of AEPs less than 50 percent; (4) other streamgages in the geographic vicinity also are considered to have mixedpopulation characteristics; and (5) the streamgage was considered by Parrett and Johnson (2004) to have mixed-population characteristics. In most cases that the mixed-population approach was used, at least three of the criteria were met.

An important characteristic of the informed-user adjustments for handling atypical upper-tail peak-flow records is the use of the at-site station skew coefficient instead of the weighted skew coefficient. Bulletin 17C indicates that mixedpopulation peak-flow records can result in frequency curves with abnormally large skew coefficients reflected by abnormal slope changes in the peak-flow plotting positions. Presumably, the Bulletin 17C statements on skew abnormality relate to comparison of mixed populations to homogeneous populations. For many Montana streamgages with mixed-population characteristics, large skew coefficients and unusual slope changes are typical and reflect the probability characteristics of the underlying flood-generating processes. Thus, use of the at-site station skew coefficient, instead of the weighted skew coefficient, can more appropriately represent the peak-flow distributional characteristics. In most cases where the at-site station skew coefficient is applied for mixed-population peakflow records, the use of the at-site station skew coefficient is consistent with Bulletin $17 \mathrm{C}$ guidelines that permit altering the skew-weighting procedure when the station and generalized skews differ by more than 0.5 . If the frequency curve using the at-site station skew coefficient is considered to appropriately represent the peak-flow plotting positions, the analysis is accepted. If the frequency curve using the at-site station skew coefficient is considered to not well represent the plotting positions, a manual PILF threshold is defined.

A manual PILF threshold manipulates the frequency analysis so that the mixed-population records are more effectively treated as coming from a single population. For many of the Montana streamgages considered to have mixedpopulation characteristics, a somewhat distinct downward break in slope is apparent in the plotting position pattern in the lower tail of the frequency distribution. Presumably, for mixed-population peak-flow records, unusual changes in slope might reflect transitions in peak-flow event types within the frequency distribution. The downward breaks in slope in the lower tail of the frequency distribution can distort the fit of the frequency curve in the upper tail where the data are more representative of important flood events. For some Montana streamgages considered to have mixed-population characteristics, downward breaks in slope in the lower tail of the frequency distribution are not apparent; however, the fit of the frequency curve in the upper tail might still be improved by applying a manual PILF.

Frequency curves for Tenmile Creek near Rimini, Montana (streamgage 06062500; map number 101; fig. 1) indicate differences between standard procedures (fig. $4 A$ ) and informed-user adjustments for handling atypical upper-tail peak-flow records (fig. 4B). Frequently, mixed-population peak-flow records will exhibit multiple distinct and unusual slope changes in the peak-flow plotting positions, which is the case for streamgage 06062500 (fig. 4). The use of the MGBT in the standard procedures identifies two low PILFs but does not appropriately identify a distinct break in slope in the lower tail of the frequency distribution (fig. 4A). Without appropriate censoring of the lower tail, the frequency curve deviates from the plotting positions throughout a large range in AEPs. Further, many peak-flow plotting positions are outside of the 90-percent confidence intervals. The use of a manual PILF threshold and the at-site station skew coefficient in the informed-user adjustments for handling atypical upper-tail peak-flow records provides appropriate fit of the peak-flow plotting positions (fig. $4 B$ ) with no peak-flow plotting positions outside of the 90 -percent confidence intervals. The adjustments result in a 1-percent AEP peak-flow quantile of $1,450 \mathrm{ft}^{3} / \mathrm{s}$ (fig. $4 B$ ), which is about 28 percent larger than the 1 -percent AEP peak-flow quantile of 1,130 ft $3 / \mathrm{s}$ (fig. $4 A$ ) determined using standard procedures.

There are 16 example streamgages that indicate various aspects of informed-user adjustments for handling atypical upper-tail peak-flow records (table 3). Application of the adjustments in a given frequency analysis is indicated in the column "Primary reason for deviation from standard Bulletin 17C procedures" in table 1-4 of McCarthy and others (2018a).

Large at-site station skew coefficients for the example atypical upper-tail streamgages are reflected in a mean atsite station skew coefficient of 1.86; nine of the example streamgages have at-site station skew coefficients greater than 2 and two of the example streamgages have at-site station skew coefficients greater than 3 . The large at-site station skew coefficients are not restricted to short record streamgages. For example, streamgages 05010000, 05011000, 05012500, and 05014500 (map numbers 1, 2, 4, and 9, respectively; fig. 1) are on streams in the headwaters of the Hudson Bay Basin near the Continental Divide and for all of the four streamgages the 1964 peak flow is the maximum peak of record. The number of years of record for the four streamgages range from 17 to 103 and the at-site station skew coefficients range from 2.382 to 3.117 (table 1-4 in McCarthy and others, 2018a). The atsite station skew coefficient for the longest record streamgage ( $05014500 ; 103$ years) is 2.632 . For all four streamgages, the at-site frequency analyses result in an AEP for the 1964 peak of between 0.5 and 0.2 percent (tables 1-5 and 1-7 in McCarthy and others, 2018a).

The EMA procedures might not be precise for analysis skew coefficients outside of the range -1.4 to +1.4 ; many of the Montana atypical upper-tail datasets are outside of that range. However, examination of frequency curve fits in relation to peak-flow plotting positions and also comparison of the EMA frequency curves with previously reported frequency analyses (Parrett and Johnson, 2004; Sando and others, 2016a) indicate that the EMA procedures provide reliable frequency estimates even when the analysis skew coefficients are outside of the indicated range. 


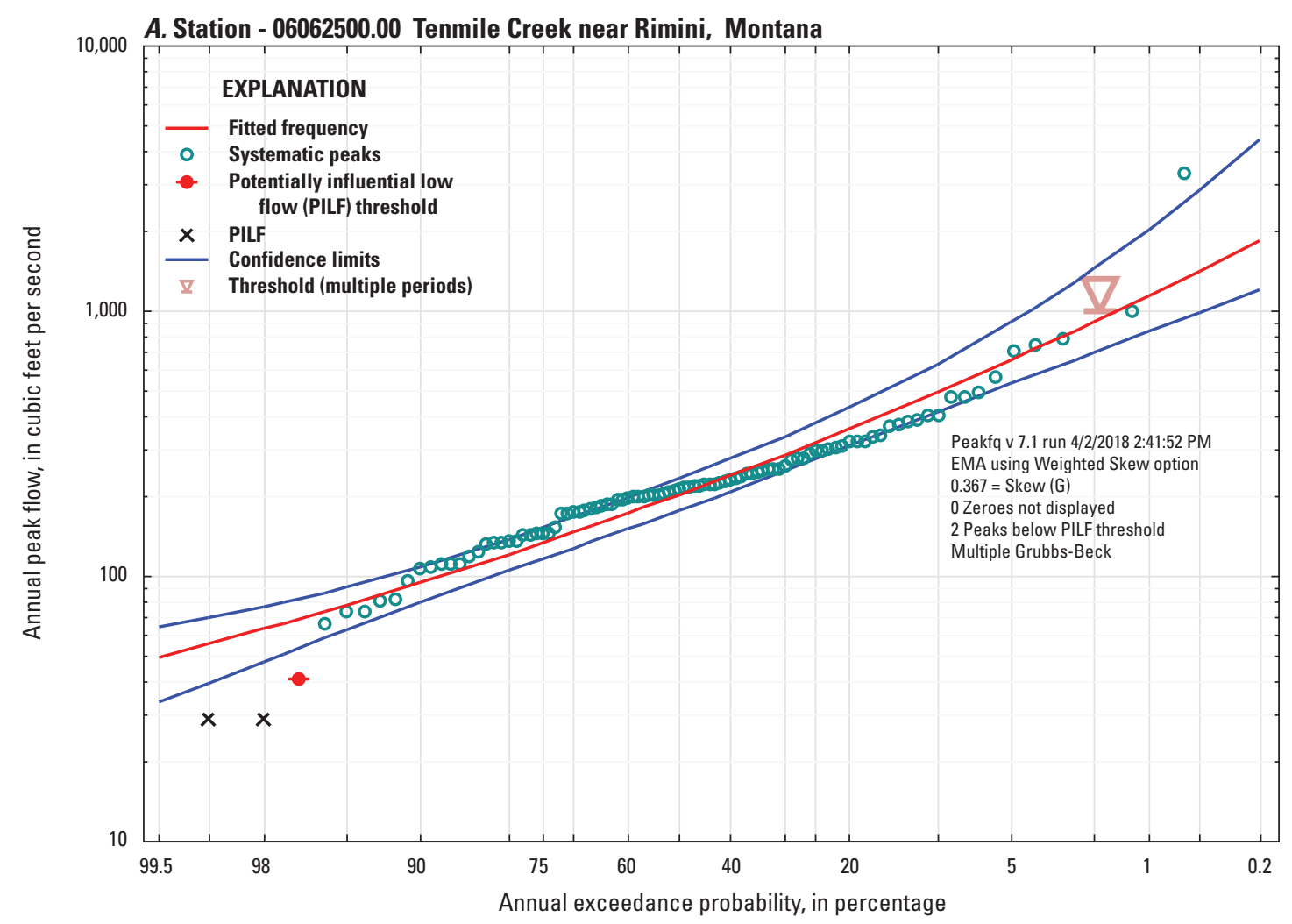

B. Station - 06062500.00 Tenmile Creek near Rimini, Montana

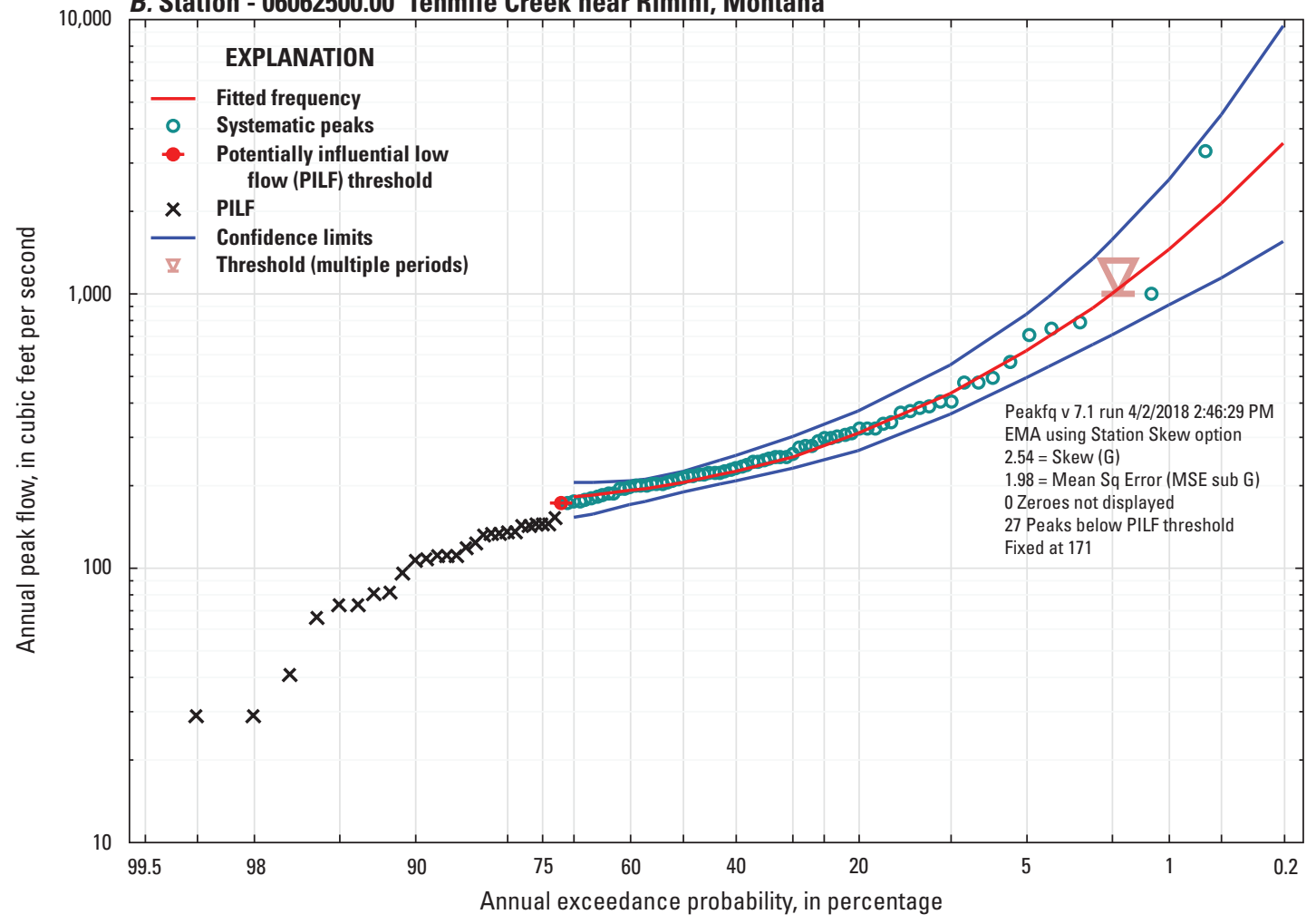

Figure 4. PeakFQv7.1 output—Peak-flow frequency curves for Tenmile Creek near Rimini, Montana (streamgage 06062500). $A$, Frequency curve using standard procedures; $B$, Frequency curve using informeduser adjustments for handling atypical upper-tail peak-flow records. 
Uncertainties in frequency estimates inherently increase with decreasing AEPs. Most of the frequency curves for the 16 example atypical upper-tail streamgages are strongly influenced by one or more unusually large peak flows that are substantially elevated above the main body of peak flows, which further contributes to increasing uncertainty. The unusually large peak flows also contribute to the generally large positive at-site station skew coefficients, which typically result in frequency curves that are strongly concave upwards. In contrast, frequency curves for negative skew coefficients are inherently concave downwards, which are more hydrologically realistic in that they tend to "flatten out," or asymptotically approach an undefined horizontal line that conceptually represents somewhat of an upper limit in peak-flow potential at very small AEPs (typically much less than 0.2 percent). The adjustments that were applied for the 16 example atypical upper-tail streamgages substantially improved the fits of the frequency curves throughout the range of the plotting positions. However, extending frequency curves with large positive skews to progressively smaller AEPs could yield frequency estimates that are unrealistically large (Daniel G. Driscoll, U.S. Geological Survey, written commun., May 2017). Additional research regarding other alternative approaches for fitting probability distributions for peak-flow datasets with large positive at-site station skew coefficients would be highly beneficial. Compilation and documentation of paleoflood data would provide important information for improved characterization of the upper tail of the frequency curve for Montana mixed-population streamgages; however, currently (2018) the WY-MT WSC methods are considered to provide reasonably reliable frequency analyses based on best-available data and methods.

\section{Adjustments for Handling Atypical Lower-Tail Peak-Flow Records}

The Bulletin 17C adoption of the MGBT and the EMA procedures provides for improved identification and handling of low-lying data points that have a distorting effect on the fitted frequency curve. For nearly all Montana streamgages, the use of the MGBT results in improved identification of PILFs; however, in infrequent cases unrelated to regulation and atypical upper-tail considerations, a manual PILF threshold is considered to provide better representation of the data than the MGBT.

Many CSGs in Montana have been located along ephemeral channels that seldom flow, and many gaged streams can be subject to low- or zero-streamflow conditions for extended periods. Probability plots of peak flows for streamgages that are strongly affected by low- or zero-streamflow values frequently deviate from typical patterns in the lower tail of the frequency distribution. The atypical patterns include abnormal slope changes that sometimes result in sharp deviations from the main body of peak flows. For streamgages strongly affected by low- or zero-streamflow values and having short periods of record (less than about 20 years) the transition from the main body of peak flows to the very low peak flows can be abrupt and difficult to appropriately represent in the frequency analysis. In some cases, the MGBT results in screening the entire transition from the main body of peak flows to the very low peak flows as less than the PILF threshold. In such cases, the resultant frequency curves can be atypically flat and, when extended to large peak-flow quantiles, produce unusually low peak-flow quantiles in the upper tail of the frequency curve that are considered unrepresentative of the hydrologic regime.

Frequency curves for Denniel Creek near Val Marie, Saskatchewan (streamgage 06163400; map number 337; fig. 1) indicate differences between standard procedures (fig. $5 \mathrm{~A}$ ) and adjustments for handling atypical lower-tail peak-flow records (fig. 5B). Streamgage 06163400 has a short period of record with insufficient representation of an appropriate range in peak flows. The use of the MGBT in the standard procedures identifies eight PILFs and results in a flat frequency curve strongly affected by only seven uncensored peak flows (fig. $5 A$ ). The use of a manual PILF threshold in the adjustments for handling atypical lower-tail peak-flow records (fig. 5B) allows inclusion of more uncensored peak flows in the frequency analysis and is considered to provide better representation of the hydrologic regime.

For some streamgages with somewhat substantial periods of record (greater than about 20 years), the MGBT can fail to detect distinct breaks in the peak-flow plotting positions in the lower tail of the frequency distribution; this situation often happens when the upper tail of the frequency curve is concave upward and the peak-flow data have a large standard deviation (Wilbert O. Thomas, Michael Baker International, written commun., December 2017). Frequency curves for Poplar River at international boundary (streamgage 06178000; map number 386; fig. 1) indicate differences between standard procedures (fig. 6A) and adjustments for handling atypical lower-tail peak-flow records (fig. $6 B$ ). In the lower tail of the frequency distribution, a distinct break in the peak-flow plotting positions is not detected by the use of the MGBT in the standard procedures (fig. $6 A$ ). The use of a manual PILF threshold in the adjustments for handling atypical lowertail peak-flow records (fig. $6 B$ ) appropriately identifies the detached lower-tail peak flows and results in a small adjustment to the frequency curve.

There are six example streamgages that indicate various aspects of frequency analyses for atypical lower-tail peakflow records (table 3 ). In cases that a manual PILF is used in a frequency analysis affected by atypical lower-tail peak-flow records, indication is provided in the column "Primary reason for deviation from Bulletin 17C standard procedures" in table 1-4 of McCarthy and others (2018a). 

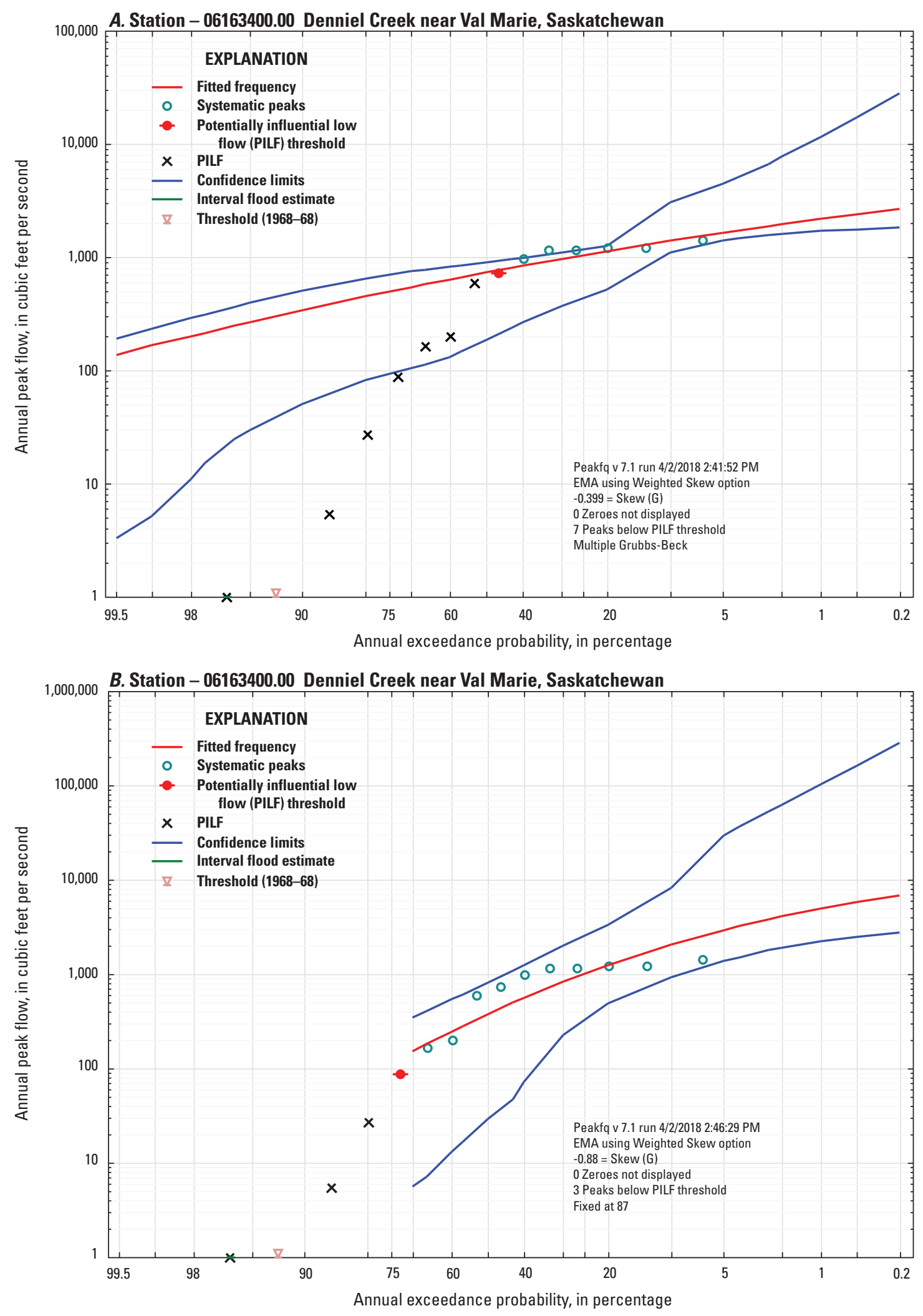

Figure 5. PeakF0v7.1 output-Peak-flow frequency curves for Denniel Creek near Val Marie, Saskatchewan (streamgage 06163400). $A$, Frequency curve using standard procedures; $B$, Frequency curve using informed-user adjustments for handling atypical lower-tail peak-flow records. 

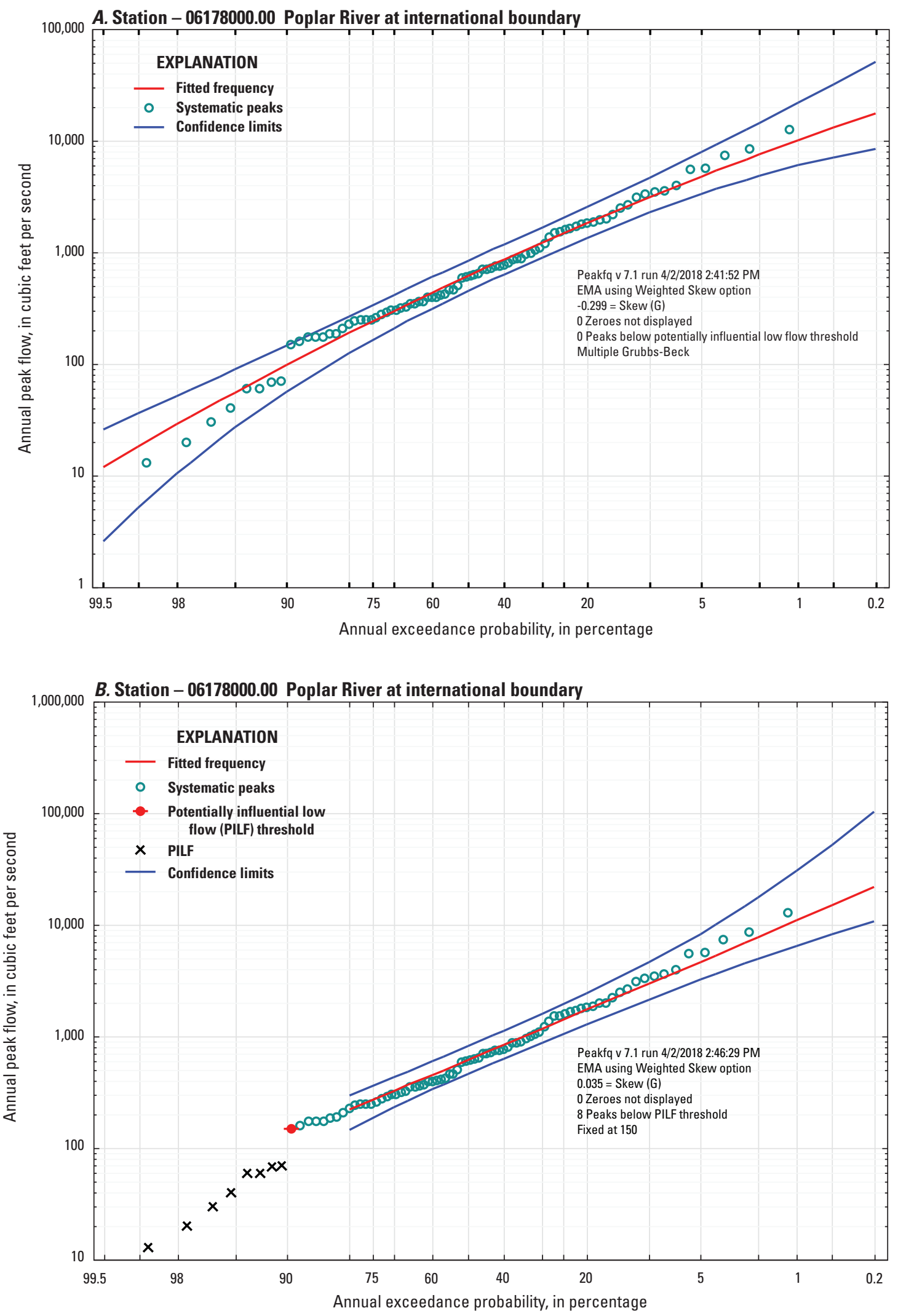

Figure 6. PeakFQv7.1 output-Peak-flow frequency curves for Poplar River at international boundary (streamgage 06178000). $A$, Frequency curve using standard procedures; $B$, Frequency curve using informeduser adjustments for handling atypical lower-tail peak-flow records. 


\section{Considerations for Interpreting At-Site Frequency Analyses}

Bulletin $17 \mathrm{C}$ indicates that the guidelines can be applied to streamgages with 10 or more years of record for AEPs greater than 1 percent; for AEPs less than 0.5 percent, augmentation with regional information, precipitation records, or paleoflood information generally is required. For informational purposes, the WY-MT WSC reports at-site frequency analyses for AEPs of 0.5 and 0.2 percent and caution should be used in relying on these low-AEP frequency analyses for critical applications. For critical applications, a user might consider frequency analyses that incorporate methods intended to improve frequency estimates, as described in the following section "Procedures for Improving At-Site Frequency Analyses."

For streamgages classified as having major dam regulation, the frequency estimates for low AEPs (less than 1 percent) for the regulated periods of record are presented for informational purposes; these low AEP frequency estimates should be used with caution in critical applications because of the possibility of unusual events, such as dam failures. Frequency estimates for higher AEPs (greater than or equal to 1 percent) generally are considered to be reliable. For many regulated streams, the potential effects of regulation diminish progressively in a downstream direction and also might be affected by variability in available storage capacity and reservoir operations. The proximity of the streamgage to the regulating dam in conjunction with the storage capacity and dedicated flood-control storage are possible considerations when evaluating use of the low AEPs.

The climatic conditions of the specific time period during which the data were collected can substantially affect how well the at-site frequency results represent long-term hydroclimatic conditions. Differences in the timing of the periods of record can result in substantial inconsistencies in frequency results for hydrologically similar streamgages. Potential for inconsistency is increased for short-term streamgages that have less than about 25 years of peak-flow records. The representativeness of the frequency estimates for a short-term streamgage can be improved by procedures described in the following section "Procedures for Improving At-Site Frequency Analyses."

\section{Procedures for Improving At-Site Frequency Analyses}

Specific procedures can sometimes be applied to improve at-site frequency analyses, especially for short-term streamgages. Frequency estimates for unregulated streamgages that meet the criteria and limitations of applicable regional regression equations (RREs) generally can be improved by weighting the at-site frequency estimates with frequency estimates from RREs as described in appendix 9 of Bulletin
17C. For multiple streamgages on the same stream channel, frequency estimates might be improved by record extension as discussed in appendix 8 of Bulletin 17C.

\section{Procedures for Weighting with Regional Regression Equations}

The uncertainty of peak-flow frequency estimates can be reduced by combining the at-site frequency estimates with other independent estimates, such as the RREs to obtain a weighted frequency estimate at the streamgage. As indicated in Bulletin 17C, the weighted frequency method assumes that the two frequency estimates are independent and unbiased, and the variances are reliable and consistent. The weighted frequency method, presented in appendix 9 of Bulletin 17C, uses the log-transformed frequency estimates and variances from two separate estimates ( $a$ and $b$ ) to compute a weighted frequency estimate $(w t d)$ and confidence intervals using the following equations:

$$
\begin{gathered}
X_{a}=\log _{10}\left(Q_{a}\right) \\
X_{b}=\log _{10}\left(Q_{b}\right) \\
X_{w t d}=\frac{X_{a} * V_{b}+X_{b} * V_{a}}{V_{b}+V_{a}} \\
V_{w t d}=\frac{V_{b} * V_{a}}{V_{b}+V_{a}} \\
U_{w t d}=X_{w t d}+1.64 \sqrt{V_{w t d}} \\
L_{w t d}=X_{w t d}-1.64 \sqrt{V_{w t d}}
\end{gathered}
$$


where

$Q \quad$ is the frequency estimate for estimation method $a, b$, or $w t d$, in cubic feet per second;

$X \quad$ is the log-transformed frequency estimate for estimation method $a, b$, or $w t d$;

$V$ is the variance for estimation method $a$, $b$, or $w t d$;

$U_{w t d}$ and $L_{w t d}$ are the upper and lower log-transformed confidence limits for the two-tailed 90-percent confidence interval;

1.64 is the one-tailed student's $t$ value for the 95-percent (upper) and 5-percent (lower) confidence limits assuming infinite degrees of freedom; and $C I_{U, w t d}$ and $C I_{L, \text { wtd }}$ are the upper and lower limits of the two-tailed 90-percent confidence interval for the weighted frequency estimate, in cubic feet per second, and all other terms are as previously defined.

The weighted frequency method using equations 1 through 9 calculates confidence intervals for the weighted estimate using the weighted variance; however, this method does not take into account the confidence intervals for an at-site frequency analysis computed using EMA. Thus, the WY-MT WSC developed a method for weighting an at-site frequency estimate with another independent estimate that preserves the characteristics of the confidence intervals computed using EMA. This method for weighting the at-site frequency analysis with another independent estimate uses the effective variances of the upper and lower confidence intervals $\left(V_{e f f, U}\right.$ and $V_{\text {eff:L } L}$ ) from the at-site analysis to compute confidence intervals for the weighted estimates as shown in equations 10 through 17 :

$$
\begin{gathered}
U_{a t-\text { site }}=\log _{10}\left(C I_{U, a t-\text { site }}\right) \\
L_{a t-\text { site }}=\log _{10}\left(C I_{L, a t-\text { site }}\right) \\
V_{\text {eff }, U}=\left(\frac{U_{a t-\text { site }}-X_{a t-\text { site }}}{1.64}\right)^{2} \\
V_{\text {eff }, L}=\left(\frac{X_{a t-\text { site }}-L_{a t-\text { site }}}{1.64}\right)^{2} \\
V_{w t d, U}=\frac{V_{e f f, U} * V_{b}}{V_{e f f, U}+V_{b}}
\end{gathered}
$$

$$
\begin{gathered}
V_{w t d, L}=\frac{V_{e f f, L} * V_{b}}{V_{e f f, L}+V_{b}} \\
U_{w t d}=X_{w t d}+1.64 \sqrt{V_{w t d, U}} \\
L_{w t d}=X_{w t d}-1.64 \sqrt{V_{w t d, L}}
\end{gathered}
$$

where

$$
\begin{aligned}
& C I_{U, \text { atssite }} \text { and } C I_{L, \text { atsite }} \text { are the upper and lower limits of the } \\
& U_{a t-s i t e} \text { and } L_{\text {at-site }} \quad \text { are the upper and lower log-transformed } \\
& V_{\text {eff }, U} \text { and } V_{\text {eff }, L}
\end{aligned}
$$

Within the 99 example streamgages (table 3 ), there are 71 streamgages with adjusted frequency analyses based on weighting with RREs from Sando, Roy, and others (2016). Those 71 streamgages are classified as unregulated or minor regulation and met the criteria and limitations of the applicable RREs.

\section{Considerations for Interpreting Frequency Results for Weighting with Regional Regression Equations}

Although weighted estimates generally can improve the reliability and accuracy of the at-site estimates, users are cautioned to investigate the at-site and weighted estimates prior to application of the weighted estimates. Montana has large and complex hydrologic regions with large hydrologic variability within the regions that is not always sufficiently captured in the RREs or in the small number of basin characteristics (explanatory variables) in the RREs. Also, the weighting by variance method can result in substantial differences between an at-site estimate and a weighted estimate even for streamgages with long periods of record. Thus, various situations might not be fully accommodated in the RRE weighting process. For example, RREs developed for the Southwest hydrologic region only incorporated a small number of streamgages with mixed-population peak-flow records; thus, the RREs might not sufficiently represent areas with 
mixed-population characteristics. Tenmile Creek near Rimini, Montana (streamgage 06062500; map number 101; fig. 1) has 99 years of peak-flow records and adjustments for handling mixed-population peak-flow records were used for the at-site analysis that had a 0.2-percent AEP flood quantile of 3,500 $\mathrm{ft}^{3} / \mathrm{s}$; when weighted with the RREs, the 0.2-percent AEP flood quantile decreased by about 39 percent to $2,150 \mathrm{ft}^{3} / \mathrm{s}$ (table $1-7$ in McCarthy and others, 2018a).

\section{Procedures for Modified Maintenance of Variance Extension Type III Record Extension}

Bulletin 17C presents a Maintenance of Variance recordextension approach that incorporates aspects of the "Two Station Comparison" (Matalas and Jacobs, 1964; Bulletin 17B) and MOVE.3 (Vogel and Stedinger, 1985). The approach is based on transferring information from a nearby long-term streamgage to a short-term streamgage based on the correlation of concurrent peak-flow records. Specific criteria for application of the Bulletin 17C record-extension approach include at least 7 or 8 years of concurrent peak-flow records with a Pearson correlation coefficient greater than 0.80 . The approach is specifically limited to record-extension applications involving a single long-term streamgage and a single short-term streamgage.

The WY-MT WSC uses record extension in cases of multiple streamgages on the same large river with variable periods of record but high cross correlation in concurrent years. In many cases, streamgages that are adjusted using record extension cannot be adjusted by weighting with RREs because of regulation or large drainage areas that are outside the criteria and limitations of applicable RREs. For each streamgage, record-extension procedures synthesize estimated peak flows for years of missing record; this allows synchronization of the variable periods of record to a common longterm base period. Frequency analysis of the extended datasets, consisting of recorded and synthesized peak flows, provides synchronized frequency estimates that might be useful for several frequency applications, including flood-plain mapping. The synchronized frequency estimates are considered general estimates of frequency relations among streamgages on the same stream channel that might be expected if the streamgages had been operated during the same long-term base period.

The record-extension applications of the WY-MT WSC are not well addressed by the Bulletin $17 \mathrm{C}$ record-extension approach, primarily because of the limitation to record-extension applications involving a single long-term streamgage and a single short-term streamgage. As such, modified MOVE. 3 procedures were developed for the WY-MT WSC recordextension applications. The general approach for using the modified MOVE. 3 procedures to adjust at-site frequencies involved (1) determining appropriate base periods for the streamgages on the large rivers, (2) synthesizing peak-flow data for the streamgages with incomplete peak-flow records during the base periods by using the modified MOVE. 3 procedures, (3) conducting frequency analysis on the extended dataset for each streamgage, and (4) adjusting the confidence intervals of the frequency analysis to appropriately represent the use of the modified MOVE. 3 procedures.

\section{Definition of Base Periods}

For each large river (or in some cases a subreach of the river), the base period typically extends from the earliest to the latest year of peak-flow records for streamgages on the river or subreach. For some large rivers, all streamgages are affected by the same major dam or canal regulation structure (as described by McCarthy and others, 2016). In such cases, the base period is restricted to the period after the start of the regulation. For some large rivers, some reaches are unregulated, whereas other reaches are regulated. In such cases, different base periods for different reaches are defined to accommodate the variability in unregulated and regulated conditions.

\section{Application of Modified Maintenance of Variance Extension Type III Procedures to Synthesize Peak-Flow Data}

The modified MOVE. 3 procedures used by the WY-MT WSC generally follow the MOVE. 3 methods of Vogel and Stedinger (1985) that involve synthesis of missing records for a short-record streamgage (hereinafter "target streamgage") based on information collected from a single longer-record streamgage (hereinafter "index streamgage"). The modified MOVE. 3 procedures require at least 7 or 8 years of concurrent peak-flow records for the target and index streamgages with a Pearson correlation coefficient greater than 0.80 . As a modification to the Vogel and Stedinger (1985) MOVE.3 methods, the WY-MT WSC, in some cases, uses a mixed-streamgage approach for the MOVE. 3 procedure (similar in application to Alley and Burns [1983] and Sando and others [2008] using the Maintenance of Variance Extension Type I procedure [Hirsch, 1982]), such that multiple index streamgages are used to synthesize missing records for a single target streamgage. For multiple streamgages on the same large river, a mixed streamgage approach can provide more accurate record synthesis within a more complete base period than the use of a single index streamgage.

The computations of the MOVE. 3 analysis are described by Vogel and Stedinger (1985) and summarized in Bulletin 17C. The mixed-streamgage approach applied by the WY-MT WSC for synthesizing missing records for a target streamgage using multiple index streamgages involved an iterative process. First, a MOVE. 3 analysis was conducted using the index streamgage with the highest correlation with the target streamgage and as many missing records as possible were synthesized. Second, a MOVE. 3 analysis was conducted using the index streamgage with the next highest correlation and as many missing records as possible were synthesized. Before conducting the second MOVE. 3 analysis, any years that were synthesized from the first MOVE. 3 analysis were removed 
from the second index streamgage dataset. After the second MOVE. 3 analysis, if necessary, MOVE. 3 analyses were conducted using additional index streamgages, following the approach for the second MOVE.3 analysis, until all missing records in the base period had been synthesized.

The errors associated with the modified MOVE. 3 procedures are difficult to precisely quantify; Vogel and Stedinger (1985) do not include a method for estimating the MOVE.3 analysis errors. Datasets that satisfy the high-correlation criteria of Vogel and Stedinger (1985) might be presumed to provide reliable record extension; however, estimates of analysis errors are important for understanding potential uncertainties that might not be represented by the correlation coefficients alone. In the modified MOVE. 3 procedures, a method for estimating the standard error was adopted based on communications with a contributor to appendix 8 ("Record Extension with Nearby Sites") of Bulletin 17C (Wilbert O. Thomas, Michael Baker International, written commun., November 2016). Initially, a standard error was calculated as the standard deviation of the residuals from an ordinary least squares (OLS) regression of the concurrent records of the target and index streamgages; this standard error represents an OLS formulation of the analysis that underestimates the error of the modified MOVE. 3 formulation. The OLS standard error $\left(O L S_{S E}\right)$ for an individual index streamgage $(i)$ then was adjusted to estimate the modified MOVE.3 standard error $\left(M O V E 3_{S E}\right)$ by multiplying times the following adjustment factor:

$$
\begin{gathered}
A F_{S E}=\sqrt{2 /(1+\rho)} \\
M O V E 3_{S E}=O L S_{S E} * A F_{S E} \\
M O V E 3_{S E}=O L S_{S E} * \sqrt{2 /(1+\rho)}
\end{gathered}
$$

where

$$
\begin{aligned}
& A F_{S E} \quad \text { is the adjustment factor for the OLS standard } \\
& \text { error; } \\
& \rho \quad \text { is the Pearson correlation coefficient for the } \\
& \text { concurrent records of the target and index }
\end{aligned}
$$

In the case of mixed-streamgage modified MOVE. 3 analyses, the OLS standard error $\left(O L S_{S E, i}\right)$ and Pearson correlation coefficient $\left(\rho_{i}\right)$ were calculated for each index streamgage (i). Then, a weighted OLS standard error and a weighted
Pearson correlation coefficient was calculated by multiplying by the number of peak flows synthesized $\left(n_{2, i}\right)$ for each index streamgage; the resultant products then were summed and divided by the total number of synthesized peak flows.

$$
\begin{aligned}
O L S_{S E, w t d} & =\frac{\sum_{i=1}^{x}\left(O L S_{S E, i} * n_{2, i}\right)}{\sum_{i=1}^{x} n_{2, i}} \\
\rho_{\text {wtd }} & =\frac{\sum_{i=1}^{x}\left(\rho_{i}^{*} n_{2, i}\right)}{\sum_{i=1}^{x} n_{2, i}}
\end{aligned}
$$

where

$O L S_{S E, w t d} \quad$ is the weighted OLS standard error;

$\rho_{\text {wtd }} \quad$ is the weighted Pearson correlation coefficient;

$x \quad$ is the number of index streamgages; and

$n_{2, i} \quad$ is the number of synthesized peak flows from index streamgage $i$.

Thus, for a mixed-streamgage modified MOVE. 3 analysis, $M O V E 3_{S E}$ becomes

$$
M O V E 3_{S E}=O L S_{S E, w t d} * \sqrt{2 /\left(1+\rho_{w t d}\right)}
$$

\section{Procedures for Frequency Analysis of Extended Peak- Flow Datasets}

For an individual streamgage, the modified MOVE. 3 procedures synthesize estimated peak flows for years of missing record and produce an extended dataset consisting of recorded and synthesized peak flows for a given base period. In frequency analysis, an extended dataset is treated identically to an at-site dataset that only consists of recorded data; thus, the frequency-analysis procedures for an extended dataset are described in the section "Procedures for At-Site Frequency Analyses."

Uncertainties for frequency analyses on extended datasets are larger than would be obtained by collecting systematic records for the same number of years represented by the base period. Precise calculation of confidence intervals about the frequency estimates for the modified MOVE. 3 extended datasets is difficult. In the application of the modified MOVE. 3 procedures, a method for adjusting the confidence intervals was adopted based on communications with a contributor to appendix 8 ("Record Extension with Nearby Sites") of Bulletin 17C (Wilbert O. Thomas, Michael Baker International, written commun., November 2016).

The adopted method uses the confidence intervals determined by the EMA frequency analysis performed on extended datasets $\left(\mathrm{N}_{\text {total }}\right.$ years of record), in conjunction with the estimated equivalent years of record from the modified MOVE. 3 analysis $\left(M O V E 3_{E Y R, i}\right)$. The equivalent years of record is 
computed for the modified MOVE. 3 analysis for each index streamgage $(i)$ as follows:

$$
\operatorname{MOVE3}_{E Y R, i}=n_{e, i}+n_{1, i}
$$

where

$M O V E 3_{E Y R, i} \quad$ is the estimated equivalent years of record for the combined concurrent recorded peak flows and synthesized peak flows for each index streamgage $i$;

$n_{l, i} \quad$ is the number of concurrent peak flows between the target streamgage and index streamgage $i$; and

$n_{e, i} \quad$ is the equivalent number of peak flows being synthesized from the index streamgage $i$.

For each index streamgage $(i)$ the number of concurrent peak flows between the index and target streamgage $\left(n_{l, i}\right)$ is known, and the equivalent years of record from the modified MOVE.3 analysis $\left(M O V E 3_{E Y R, i}\right)$ is computed following Vogel and Stedinger (1985); thus, the equivalent years of record for the synthesized data for an individual target streamgage $\left(n_{e, i}\right)$ is estimated and a final adjustment factor for the confidence intervals is computed:

$$
\begin{gathered}
n_{e, i}=M O V E 3_{E Y R, i}-n_{1, i} \\
A F_{C I}=\frac{N_{\text {total }}}{n_{r}+\sum_{i=1}^{x} n_{e, i}}
\end{gathered}
$$

where

$$
\begin{gathered}
N_{\text {total }} \quad \begin{array}{l}
\text { is the total number peak flows in the target } \\
\text { streamgage extended dataset; }
\end{array} \\
A F_{C I} \quad \text { is the adjustment factor for the confidence } \\
\text { intervals; and } \\
n_{r} \quad \text { is the number of years of recorded data at the } \\
\text { target streamgage, and all other terms as } \\
\text { previously defined. }
\end{gathered}
$$

It is important to differentiate between $n_{1}$ and $n_{r}$. The number of concurrent years of record used in the modified MOVE. 3 procedure is $n_{i}$; however, the target streamgage might have additional peak-flow records that are not concurrent with the index streamgages, so the number of recorded peak flows for the target streamgage $\left(n_{r}\right)$ could be greater than the number of concurrent peak flows between the target streamgage and the index streamgage $\left(n_{1}\right)$.

The final adjusted confidence intervals for the at-site MOVE. 3 procedure are calculated using the following equations:

$$
C I_{U, a d j}=Q_{M O V E 3}+A F_{C I}\left(C I_{U, M O V E 3}-Q_{M O V E 3}\right)
$$

$$
C I_{L, a d j}=Q_{M O V E 3}-A F_{C I}\left(Q_{M O V E 3}-C I_{L, M O V E 3}\right)
$$

where

$$
C I_{U, a d j} \text { and } C I_{L, a d j} \quad \text { are the adjusted upper and lower }
$$
confidence intervals for the frequency analysis on the extended dataset;

$$
\begin{array}{cc}
Q_{\text {MOVE3 }} \quad \begin{array}{c}
\text { is the peak-flow quantile for the } \\
\text { frequency analysis on the } \\
\text { extended dataset; and }
\end{array} \\
C_{U, M O V E 3} \text { and } C I_{L, M O V E 3} \\
\begin{array}{r}
\text { are the pre-adjustment upper and } \\
\text { lower confidence intervals for } \\
\text { the frequency analysis on the } \\
\text { extended dataset. }
\end{array}
\end{array}
$$

There are eight example streamgages on two large rivers (the Big Hole River and the Yellowstone River upstream from Billings, Montana) that indicate various aspects of the modified MOVE. 3 record extension for adjusting at-site frequency analyses (table 3). Documentation on the frequency analyses on the extended datasets is presented in table 1-4 of McCarthy and others (2018a). Documentation of the modified MOVE.3 record-extension procedures is presented in table 1-6 of McCarthy and others (2018a). The frequency results are presented in table 1-7 of McCarthy and others (2018a). The frequency curves for the extended datasets are presented with upper and lower confidence intervals in separate worksheets in McCarthy and others (2018a) by streamgage identification number, and tables for each frequency analysis are included frequency analysis with indication of recorded peak flows and synthesized peak flows.

\section{Considerations for Interpreting Frequency Results for Extended Peak-Flow Datasets}

The modified MOVE. 3 record-extension frequency estimates incorporate information from nearby streamgages (generally on the same river) and are considered to be more representative of actual peak-flow frequency relations during the base periods than frequency estimates derived from the shorter-term, sometimes sporadic, gaged records. It is important to understand the intended use of the frequency estimates based on analysis of the combined recorded and synthesized datasets. The frequency estimates are considered general estimates of frequency relations among streamgages on the same stream channel that might be expected if the streamgages had been gaged during the same long-term base period. Caution should be used when using the frequency estimates for important applications, such as critical structure design. For critical structure-design applications based on a given streamgage, a conservative approach would be to select the higher of the at-site frequency estimate and the modified MOVE. 3 recordextension frequency estimate. 


\section{Methods for Peak-Flow Frequency Reporting}

This section describes an approach for timely publication of updated frequency analyses that involves thorough documentation of frequency-analysis methods in an interpretive report in conjunction with a separate data release consisting of tables and graphical plots for example streamgages that include information concerning the interpretive decisions involved in the frequency analyses.

The section "Methods for Peak-Flow Frequency Analysis" provides documentation of WY-MT WSC frequencyanalysis methods in this interpretive report. The methods have been applied to peak-flow data through water year 2015 for 99 selected streamgages (fig. 1, table 3 ) to provide examples of the methods and considerations involved in applying the methods. The example streamgages represent all methods and considerations in frequency analysis, and a large range in various streamgage characteristics, including contributing drainage area, regulation status, and length of peak-flow records. Various information relating to the example frequency analyses (including information concerning the interpretive decisions involved in the frequency analyses) is presented in tables (described in table 4) in a separate data release (McCarthy and others, 2018a) associated with this report. In addition to the tables, the frequency curves and associated information are presented in the data release in separate worksheets for each frequency analysis; hyperlinks in the tables allow convenient access to the frequency curves and associated information. Further, the separate data release includes the input files to PeakFQv7.1, including the peak-flow data files and the analysis specification files that were used in the peakflow frequency analyses. The approach also is used to report peak-flow frequencies based on data through water year 2016 for selected streamgages in the Beaverhead River and Clark Fork Basins and also for selected streamgages in the Ruby, Jefferson, and Madison River Basins in two additional separate data releases (McCarthy and others, 2018b and 2018c, respectively).

For some period of time into the future, the frequencyanalysis methods described in the section "Methods for Peak-Flow Frequency Analysis" will continue to be used. Several potential developments might result in the need to reinvestigate best-available frequency-analysis methods and produce a new interpretive report describing the selected methods. Such developments might include (1) completion of BWLS/BGLS analyses to provide new regional skew estimates for all of Montana, (2) development of methods for identifying and accommodating temporal nonstationarity in frequency analyses, and (3) a statewide update of frequency analyses and associated development of new regional regression equations.

\section{Summary}

This report documents the methods for peak-flow frequency (hereinafter "frequency") analysis used by the U.S. Geological Survey (USGS) Wyoming-Montana Water Science Center (WY-MT WSC) following implementation of the Bulletin $17 \mathrm{C}$ guidelines. The methods are used to provide estimates of peak-flow quantiles for 50-, 42.9-, 20-, 10-, 4-, 2-, 1-, 0.5-, and 0.2-percent annual exceedance probabilities (AEPs) for streamgages operated by the WY-MT WSC. These AEPs correspond to 2-, 2.33-, 5-, 10-, 25-, 50-, 100-, 200-, and 500 -year recurrence intervals, respectively.

The report reviews the Bulletin 17B and Bulletin 17C guidelines and discusses selection of the Bulletin 17C guidelines in conjunction with specific informed-user adjustments as the best-available frequency-analysis method with respect to Montana peak-flow datasets. Standard procedures of the WY-MT WSC for implementing the Bulletin 17C guidelines include (1) the use of the Expected Moments Algorithm (EMA) analysis for fitting the log-Pearson Type III distribution, incorporating historical information where applicable; (2) the use of weighted skew coefficients (based on weighting at-site station skew coefficients with generalized skew coefficients from the Bulletin 17B national skew map); and (3) the use of the Multiple Grubbs-Beck Test for identifying potentially influential low flows (PILFs; sometimes also referred to as "Potentially Influential Low Floods").

For some streamgages, the peak-flow records are not well represented by the standard procedures and require informeduser adjustments. The specific characteristics of peak-flow records addressed by the adjustments include (1) regulated peak-flow records, (2) atypical upper-tail peak-flow records, and (3) atypical lower-tail peak-flow records. In all cases, the informed-user adjustments use the EMA fit of the log-Pearson Type III distribution using the at-site station skew coefficient, a manual PILF threshold, or both.

Appropriate methods can be applied to at-site frequency estimates to provide improved representation of long-term hydroclimatic conditions. Frequency estimates for unregulated streamgages generally can be improved by weighting the at-site frequency estimates with frequency estimates from regional regression equations (RREs). Also, for multiple streamgages on the same stream channel, frequency estimates might be improved by using record extension. The methods for improving at-site frequency estimates by weighting with RREs and by record extension are described.

Frequency analyses were conducted for 99 example streamgages to indicate various aspects of the frequencyanalysis methods described in this report. The frequency analyses and results for the example streamgages are presented in a separate data release associated with this report consisting of tables and graphical plots that are structured to include 
information concerning the interpretive decisions involved in the frequency analyses. Further, the separate data release includes the input files to the PeakFQ program, version 7.1, including the peak-flow data files and the analysis specification files that were used in the peak-flow frequency analyses. Peak-flow frequencies are also reported in separate data releases for selected streamgages in the Beaverhead River and Clark Fork Basins and also for selected streamgages in the Ruby, Jefferson, and Madison River Basins.

\section{References Cited}

Advisory Committee on Water Information, 2002, Bulletin 17-B guidelines for determining flood frequency-Frequently asked questions: accessed April 30, 2007, at http:// acwi.gov/hydrology/Frequency/B17bFAQ.html.

Alley, W.M., and Burns, A.W., 1983, Mixed-station extension of monthly streamflow records: Journal of Hydraulic Engineering, v. 109, no. 10, p. 1272-1284. [Also available at http://dx.doi.org/10.1061/(ASCE)07339429(1983)109:10(1272).]

Ayalew, T.B., Krajewski, W.F., Mantilla, Ricardo, Wright, D.B., and Small, S.J., 2017, Effect of spatially distributed small dams on flood frequency-Insights from the Soap Creek watershed: Journal of Hydrologic Engineering, v. 22, no. 7, 11 p. [Also available at http://ascelibrary.org/doi/full/ 10.1061/\%28ASCE\%29HE.1943-5584.0001513.]

Barth, N. A., Villarini, Gabrielle, Nayak, M. A., and White, Kathleen, 2017, Mixed populations and annual flood frequency estimates in the western United States-The role of atmospheric rivers: Water Resources Research, v. 53, p. $257-269$.

Boner, F.C., and Stermitz, Frank, 1967, Floods of June 1964 in northwestern Montana: U.S. Geological Survey Water-Supply Paper 1840-B, 242 p. [Also available at https://pubs. er.usgs.gov/publication/wsp1840B]

Cohn, T.A., England, J.F., Berenbrock, D.E., Mason, R.R., Stedinger, J.R., and Lamontagne, J.R., 2013, A generalized Grubbs-Beck test statistic for detecting multiple potentially influential low outliers in flood series: Water Resources Research, v. 49, p. 5047-5058.

Cohn, T.A., Lane, W.L., and Baier, W.G., 1997, An algorithm for computing moments-based flood quantile estimates when historical flood information is available: Water Resources Research, v. 33, no. 9, p. 2089-2096.

Culler, R.C., and Peterson, H.V., 1953, Effect of stock reservoirs on runoff in the Cheyenne River Basin above Angostura Dam: U.S. Geological Survey Circular 223, 33 p.
Davidian, Jacob, 1984, Computation of water-surface profiles in open channels: U.S. Geological Survey Techniques of Water-Resources Investigations, book 3, chap. A15, 48 p. [Also available at http://pubs.usgs.gov/twri/twri3-a15/.]

England, J.F., Jr., Cohn, T.A., Faber, B.A., Stedinger, J.R., Thomas, W.O., Jr., Veilleux, A.G., Kiang, J.E., and Mason, R.R., 2017, Guidelines for determining flood flow frequency-Bulletin 17C: U.S. Geological Survey Techniques and Methods, book 4, chap. B5, 168 p., accessed October 2, 2017 at https://doi.org/10.3133/tm4-B5/.

Frickel, Donald, 1972, Hydrology and effects of conservation structures, Willow Creek basin, Valley County, Montana 1954-68: U.S. Geological Survey Water-Supply Paper 1532-G, 40 p. [Also available at https://pubs.er.usgs.gov/ publication/wsp1532G.]

Gesch, D., Oimoen, M., Greenlee, S., Nelson, C., Steuck, M., and Tyler, D., 2002, The National Elevation Dataset: Photogrammetric Engineering and Remote Sensing, v. 68, p. 5-11.

Griffis, V.W., and Stedinger, J.R., 2007, Evolution of flood frequency analysis with Bulletin 17: Journal of Hydrologic Engineering, v. 12, p. 281-297.

Grubbs, F.E., and Beck, Glenn, 1972, Extension of sample sizes and percentage points for significance tests of outlying observations: Technometrics, v. 14, no. 4, p. 847-854. [Also available at http://dx.doi.org/10.2307/1267134.]

Hirsch, R.M., 1982, A comparison of four streamflow record extension techniques: Water Resources Research, v. 18, p. 1081-1088.

Hirsch, R.M., 2011, A perspective on nonstationarity and water management: Journal of the American Water Resources Association, v. 47, no. 3, p. 436-446. [Also available at http://dx.doi.org/10.1111/j.1752-1688.2011.00539.x.]

Hirsch, R.H., and Ryberg, K.R., 2012, Has the magnitude of floods across the USA changed with global CO2 levels?: Hydrological Science Journal, v. 57, no. 1, p. 1-9, doi: 10.1080/02626667.2011.621895. [Also available at https:// pubs.er.usgs.gov/publication/70032624.]

Holmes, R.R., Jr., Wiche, G.J., Koenig, T.A., and Sando, S.K., 2013, Peak streamflows and runoff volumes for the Central United States, February through September, 2011: U.S. Geological Survey Professional Paper 1798-C, 60 p., accessed November 11, 2013 at https://pubs.usgs.gov/ $\mathrm{pp} / 1798 \mathrm{c} /$. 
Homer, Collin, Dewitz, Jon, Fry, Joyce, Coan, Michael, Hossain, Nazmul, Larson, Charles, Herold, Nate, McKerrow, Alexa, VanDriel, J.N., and Wickham, James, 2007, Completion of the 2001 National Land Cover Database for the conterminous United States: Photogrammetric Engineering and Remote Sensing, v. 73, no. 4, p. 337-341.

Johnson, M.V., and Omang, R.J., 1974, Floods of January 15-17, 1974 in northwestern Montana: U.S. Geological Survey Open-File Report 74-38, 8 p.

Johnson, M.V., and Omang, R.J., 1976, Floods of May-July 1975 along the Continental Divide in Montana: U.S. Geological Survey Open-File Report 76-424, 11 p.

Knowles, Noah, Dettinger, M.D., and Cayan, D.R., 2006, Trends in snowfall versus rainfall in the western United States: Journal of Climate, v. 19, p. 4545-4559. [Also available at https://doi.org/10.1175/JCLI3850.1.]

Kolars, K.A., Vecchia, A.V., and Ryberg, K.R., 2016, Stochastic model for simulating Souris River Basin precipitation, evapotranspiration, and natural streamflow: U.S. Geological Survey Scientific Investigations Report 2015-5185, 55 p. [Also available at https://pubs.er.usgs.gov/publication/ sir20155185.]

Matalas, N.C., and Jacobs, Barbara, 1964, A correlation procedure for augmenting hydrologic data: U.S. Geological Survey Professional Paper 434-E, 7 p.

McCarthy, P.M., Dutton, D.M., Sando, S.K., and Sando, Roy, 2016, Montana StreamStats - A method for retrieving basin and streamflow characteristics in Montana: U.S. Geological Survey Scientific Investigations Report 2015-5019-A, 16 p. [Also available at http://dx.doi.org/10.3133/sir20155019A.]

McCarthy, P.M., Sando, S.K., and Chase, K.J., 2018a, Peakflow frequency analyses for 99 selected streamgages in or near Montana, based on data through water year 2015: U.S. Geological Survey data release, accessed May 2018 at https://doi.org/10.5066/F7C827GQ.

McCarthy, P.M., Sando, S.K., and Chase, K.J., 2018b, Peakflow frequency analyses for 14 selected streamgages in the Beaverhead River and Clark Fork Basins Montana, based on data through water year 2016: U.S. Geological Survey data release, accessed May 2018 at http://doi.org/10.5066/ F7JW8C21.

McCarthy, P.M., Sando, S.K., and Chase, K.J., 2018c, Peakflow frequency analyses for 14 selected streamgages in the Ruby, Jefferson, and Madison River Basins, Montana, based on data through water year 2016: U.S. Geological Survey data release, accessed May 2018 at https://doi.org/10.5066/ F75Q4V99.
Mock, C.J., 1996, Climatic controls and spatial variations of precipitation in the western United States: Journal of Climate, v. 9, no. 5, p. 1111-1125. [Also available at http:// dx.doi.org/10.1175/1520-0442(1996)009<1111:CCA $\mathrm{SVO}>2.0$. $\mathrm{CO} ; 2$.

Montana Department of Military Affairs, 2010, 2010 update to the State of Montana multi-mitigation plan and statewide hazard assessment, Part 4-Flooding: accessed December 13, 2016, at http://montanadma.org/sites/default/files/Section\%204.4.3\%20Flooding_Final.pdf.

Montana Department of Revenue, 2014, Revenue Final Land Unit (FLU) classification: accessed November 7, 2016, at http://nris.mt.gov/nsdi/nris/mdb/revenue_flu.zip.

National Weather Service, 2016, Flooding in Montana: accessed December 13, 2016, at http://www.floodsafety. noaa.gov/states/mt-flood.shtml.

O'Connor, J.E., and Costa, J.E., 2003, Large floods in the United States - Where they happen and why: U.S. Geological Survey Circular 1245, 13 p. [Also available at http:// pubs.usgs.gov/circ/2003/circ1245/.]

Omang, R.J., 1992, Analysis of the magnitude and frequency of floods and the peak-flow gaging network in Montana: U.S. Geological Survey Water-Resources Investigations Report 92-4048, 70 p. [Also available at http://pubs.er.usgs. gov/publication/wri924048.]

Parrett, Charles, 1986, Simulation of rain floods on Willow Creek, Valley County, Montana: U.S. Geological Survey Water-Resources Investigations Report 86-4341, 89 p. [Also available at https://pubs.er.usgs.gov/publication/ wri864341.]

Parrett, Charles, and Johnson, D.R., 2004, Methods for estimating flood frequency in Montana based on data through water year 1998: U.S. Geological Survey Water-Resources Investigations Report 03-4308, 101 p. [Also available at http://pubs.usgs.gov/wri/wri03-4308/.]

Parrett, Charles, Carlson, D.D., Craig, G.S., and Hull, J.A., 1978, Data for floods of May 1978 in northeastern Wyoming and Southeastern Montana: U.S. Geological Survey Open-File Report 78-985, 18 p.

Parrett, Charles, Omang, R.J., and Hull, J.A., 1982, Floods of May 1981 in west-central Montana: U.S. Geological Survey Water-Resources Investigations Report 82-33, 20 p.

Pederson, G.T., Gray, S.T., Ault, Toby, Marsh, Wendy, Fagre, D.B., Bunn, A.G., Woodhouse, C.A., and Graumlich, L.J., 2011, Climatic controls on the snowmelt hydrology of the northern Rocky Mountains: Journal of Climate, v. 24, no. 6, p. 1666-1687. [Also available at http://dx.doi. org/10.1175/2010JCLI3729.1.] 
PRISM Climate Group, 2004, PRISM climate data: Oregon State University, accessed November 7, 2016, at http:// prism.oregonstate.edu.

PRISM Climate Group, 2015, 30-year normals: Oregon State University, accessed February 24, 2015, at http://www. prism.oregonstate.edu/normals/.

Rantz, S.E., and others, 1982, Measurements and computation of streamflow (volumes 1 and 2): U.S. Geological Survey Water-Supply Paper 2175, 631 p. [Also available at http:// pubs.usgs.gov/wsp/wsp2175/.]

Ryberg, K.R., Akyüz, F.A., Wiche, G.J., and Lin, W., 2015, Changes in seasonality and timing of peak streamflow in snow and semi-arid climates of the north central United States, 1910-2012: Hydrologic Processes, v. 30, p. 12081218, doi: 10.1002/hyp.10693. [Also available at http:// onlinelibrary.wiley.com/doi/10.1002/hyp.10693/epdf.]

Ryberg, K.R., Lin, W., and Vecchia, A.V., 2014, Impact of climate variability on runoff in the north-central United States: Journal of Hydrologic Engineering, v. 19, no. 1, p. 148-158. [Also available at http://ascelibrary.org/doi/pdf/10.1061/ (ASCE)HE.1943-5584.0000775.]

Ryberg, K.R., Vecchia, A.V., Akyüz, F.A., and Lin, W., 2016, Tree-ring-based estimates of long-term seasonal precipitation in the Souris River Region of Saskatchewan, North Dakota and Manitoba: Canadian Water Resources Journal/ Revue canadienne des ressources hydriques, v. 41, no. 3 , p. 412-428.

Sando, Roy, Sando, S.K., McCarthy, P.M., and Dutton, D.M., 2016, Methods for estimating peak-flow frequencies at ungaged sites in Montana based on data through water year 2011: U.S. Geological Survey Scientific Investigations Report 2015-5019-F, 30 p., http://dx.doi.org/10.3133/ sir20155019F.

Sando, S.K., Driscoll, D.G., and Parrett, Charles, 2008, Peak-flow frequency estimates based on data through water year 2001 for selected streamflow-gaging stations in South Dakota: U.S. Geological Survey Scientific Investigations Report 2008-5104, 367 p. [Also available at http://pubs. usgs.gov/sir/2008/5104/.]

Sando, S.K., McCarthy, P.M., and Dutton, D.M., 2016a, Peakflow frequency analyses and results based on data through water year 2011 for selected streamflow-gaging stations in or near Montana: U.S. Geological Survey Scientific Investigations Report 2015-5019-C, 27 p. [Also available at http:// dx.doi.org/10.3133/sir20155019C.]
Sando, S.K., McCarthy, P.M., Sando, Roy, and Dutton, D.M., 2016b, Temporal trends and stationarity in annual peak flow and peak-flow timing for selected long-term streamflowgaging stations in or near Montana through water year 2011: U.S. Geological Survey Scientific Investigations Report 2015-5019-B, 48 p. [Also available at http://dx.doi. org/10.3133/sir20155019B.]

Sauer, V.B., and Turnipseed, D.P., 2010, Stage measurement at gaging stations: U.S. Geological Survey Techniques and Methods, book 3, chap. A7, 45 p. [Also available at http:// pubs.usgs.gov/tm/tm3-a7/]

Shinker, J.J., 2010, Visualizing spatial heterogeneity of western U.S. climate variability: Earth Interactions, v. 14, no. 10, p. 1-15. [Also available at http://dx.doi. org/10.1175/2010EI323.1.]

Turnipseed, D.P., and Sauer, V.B., 2010, Discharge measurements at gaging stations: U.S. Geological Survey Techniques and Methods, book 3, chap. A8, 87 p. [Also available at http://pubs.usgs.gov/tm/tm3-a8/.]

U.S. Army Corps of Engineers, 1982, Mixed-population frequency analysis: U.S. Army Corps of Engineers Hydrologic Engineering Center, Technical Report TD-17, 42 p. [Also available at http://www.hec.usace.army.mil/publications/ TrainingDocuments/TD-17.pdf]

U.S. Army Corps of Engineers, 1985, Post-flood report-Missouri River and tributaries-spring floods 1984: U.S. Army Corps of Engineers Omaha District unclassified report, 40 p. accessed October 27, 2017, at http:/oai.dtic.mil/oai/ oai?verb=getRecord\&metadataPrefix $=$ html\&identifier= ADA149541.

U.S. Army Corps of Engineers, 1991, Ice-influenced flood stage frequency analysis: Washington, D.C., U.S. Army Corps of Engineers, Technical Letter No. 1110-2-325, 17 p.

U.S. Army Corps of Engineers, 1998, Ice jams in Montana: Hanover, New Hampshire, U.S. Army Cold Regions Research and Engineering Laboratory, accessed February 24, 2015, at http://icejams.crrel.usace.army.mil/tectran/ IEbul19.pdf.

U.S. Census Bureau, 2016, U.S. Census Bureau web site: accessed on December 13, 2016, at http://www.census.gov/.

U.S. Environmental Protection Agency, 2015, Level III and IV ecoregions of the continental United States: accessed November 1, 2016, at https:/www.epa.gov/eco-research/ level-iii-and-iv-ecoregions-continental-united-states.

U.S. Interagency Advisory Committee on Water Data, 1982, Guidelines for determining flood flow frequency: Hydrology Subcommittee, Bulletin 17B, 28 p. 
U.S. Geological Survey, 2009, Data qualification codes for USGS peak flow file, appendix A of Review and correction of the peak flow file: Office of Surface Water Technical Memorandum 09.01, 5 p., accessed December 15, 2016, at https://water.usgs.gov/admin/memo/SW/sw09.01_appendix1.pdf.

U.S. Geological Survey Office of Surface Water, 2012, Computation of annual exceedance probability (AEP) for characterization of observed flood peaks: Office of Surface Water Technical Memorandum 2013.01, 7 p., accessed December 2, 2016, at http://water.usgs.gov/admin/memo/SW/sw13.01. pdf.

U.S. Geological Survey, 2016a, National Water Information System - Web interface: accessed October 29, 2016, at https://doi.org/10.5066/F7P55KJN.

U.S. Geological Survey, 2016b, PeakFQ, version 7.1: accessed June 25, 2015, at http://water.usgs.gov/software/PeakFQ/.

U.S. Geological Survey, 2016c, Water resources of the United States: accessed December 1, 2016, at https://www2.usgs. gov/water/.

Vecchia, A.V., 2008, Climate simulation and flood risk analysis for 2008-40 for Devils Lake, North Dakota: U.S. Geological Survey Scientific Investigations Report 2008-5011, 28 p. [Also available at https://pubs.er.usgs.gov/publication/ sir20085011.]

Veilleux, A.G., Cohn, T.A., Flynn, K.M., Mason, R.R., Jr., and Hummel, P.R., 2014, Estimating magnitude and frequency of floods using the PeakFQ 7.0 program: U.S. Geological Survey Fact Sheet 2013-3108, 2 p., http://dx.doi. org/10.3133/fs20133108.

Veilleux, A.G., Stedinger, J.R., and Lamontagne, J.R., 2011, Bayesian WLS/GLS regression for regional skewness analysis for regions with large cross-correlations among flood flows, paper 1303 in World Environmental and Water Resources Congress 2011-Bearing Knowledge for Sustainability, Palm Springs, Calif., May 22-26, 2011: American Society of Civil Engineers, p. 3103-3112.

Vining, K.C., Chase, K.J., and Loss, G.R., 2013, General weather conditions and precipitation contributing to the 2011 flooding in the Mississippi River and Red River of the North Basins, December 2010 through July 2011: U.S. Geological Survey Professional Paper 1798-B, 22 p.

Vogel, R.M., and Stedinger, J.R., 1984, Flood-plain delineation in ice jam prone regions: Journal of Water Resources Planning and Management, v. 110, no. 2, p. 206-219. [Also available at http://engineering.tufts.edu/cee/people/vogel/ documents/floodplain.pdf.]
Vogel, R.M., and Stedinger, J.R., 1985, Minimum variance streamflow record augmentation procedures: Water Resources Research, v. 21, p. 715-723.

Wells, J.V.B., 1955, Floods of April 1952 in the Missouri River basin: U.S. Geological Survey Water-Supply Paper 1260-B, 264 p. [Also available at https://pubs.er.usgs.gov/ publication/wsp1260B.]

Wells, J.V.B., 1957, Floods of May-June 1953 in the Missouri River basin in Montana: U.S. Geological Survey WaterSupply Paper 1320-B, 93 p. [Also available at https://pubs. er.usgs.gov/publication/wsp1320B.]

White, K.D., 2004, Ice jam mitigation part 1-Introduction to river ice: Hanover, New Hampshire, U.S. Army Cold Regions Research and Engineering Laboratory, accessed February 24, 2015, at http://icejams.crrel.usace.army.mil/ presentations/Montana_Part_1.pdf.

Womack, J.M., 2012, Evaluation of the hydrologic effects of stock ponds on a prairie watershed: Bozeman, Montana, Montana State University, Master of Science in Civil Engineering Thesis, $121 \mathrm{p}$.

Zelt, R.B., Boughton, Greg, Miller, K.A., Mason, J.P., and Gianakos, L.M., 1999, Environmental setting of the Yellowstone River Basin, Montana, North Dakota, and Wyoming: U.S. Geological Survey Water-Resources Investigations Report 98-4269, 113 p. [Also available at http://pubs.usgs. gov/wri/wri984269/.]

For more information about this publication, contact Director, USGS Wyoming-Montana Water Science Center 3162 Bozeman Avenue Helena, MT 59601

(406) 457-5900

For additional information visit https://wy-mt.water.usgs.gov

Publishing support provided by the

Rolla Publishing Service Center 




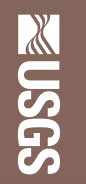

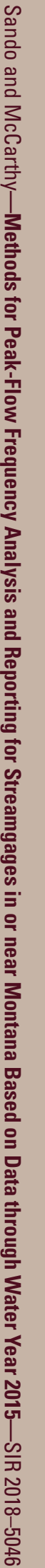

https://doi.org/10.3133/sir20185046 